
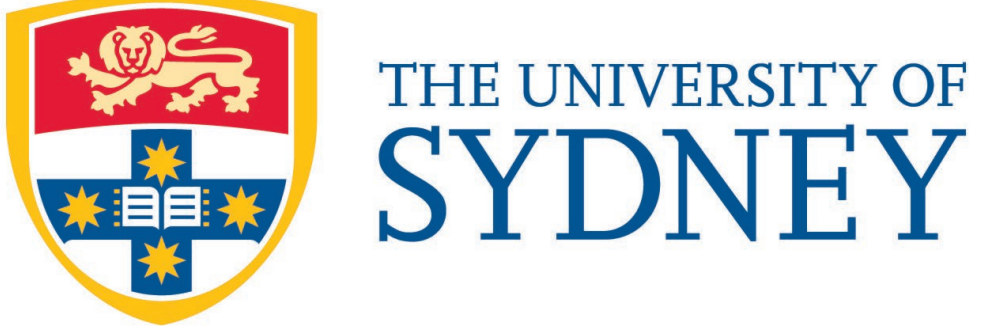

Economics Working Paper Series

$2019-12$

Natural Shocks and Marriage Markets: Evolution of Mehr and Dowry in Muslim Marriages

Shyamal Chowdhury, Debdulal Mallick, and Prabal Roy Chowdhury 


\title{
Natural Shocks and Marriage Markets: Evolution of Mehr and Dowry in Muslim Marriages
}

\author{
Shyamal Chowdhury* (University of Sydney) \\ Debdulal Mallick (Deakin University) \\ Prabal Roy Chowdhury (Indian Statistical Institute)
}

August 26, 2019

\begin{abstract}
We examine how mehr, a conditional payment from husbands to wives in the event of divorce, and dowry, a transfer from bride families to grooms at the time of marriage, have evolved in Bangladesh through natural shocks. We develop a model of marriage market in which dowry acts as a groom price, whereas mehr serves to deter inefficient divorces. Our comparative statics results show that mehr and dowry are both increasing (decreasing) in shocks that raise (lower) income, and moreover, they change at the same rate. We then exploit several natural experiments in Bangladesh that include the Green Revolution around the 1960s, the Independence War in 1971 and the famine of 1974, to explain fluctuations in the value of mehr and dowry observed in Muslim marriages. Using two household survey datasets, we find support for our theoretical predictions. To rule out alternative explanations, in particular the effect of legal changes, we use household survey data from the Indian state of West Bengal that experienced a similar increase in agricultural productivity but none of the legal changes affecting Bangladesh. These results demonstrate that natural shocks may influence the evolution of social institutions.
\end{abstract}

Key words: Mehr, Dowry, Natural Shocks, Bangladesh, West Bengal, Muslim Family Law.

JEL Classification Number: J12, O13, Z12.

*Address for Correspondence: Shyamal Chowdhury, School of Economics, The University of Sydney, NSW 2006, Australia. E-mail: shyamal.chowdhury@sydney.edu.au. 


\section{Introduction}

In this paper, we seek to examine how mehr and dowry, two well-established social institutions in Bangladesh, have evolved through natural shocks. According to Islamic law, Muslim marriage contracts require specifying a mehr, a monetary payment from the husband to the wife (Bianquis 1996, Carroll 1986a). In Bangladesh, as well as in other countries in the Indian subcontinent, mehr is a deferred payment paid only in the event of a divorce (Amin and Cain 1997, Kamal 2001, Huda 2006 and Ambrus et al. 2010) 1. Dowry, on the other hand, is a payment from the wife to the husband during marriage, and is a common practice among both Muslims as well as non-Muslims, not just in Bangladesh and the Indian sub-continent, but also in most South Asian countries 2

Despite being forbidden by law in India since 1961, in Pakistan since 1976, and in Bangladesh since 1980, dowry persists in all three settings (see Rao 1993 for India, Anderson 2003 for Pakistan, and Esteve-Volart 2004 for Bangladesh). Further, over the last few decades there has been an increase in both the incidence of dowry, as well as substantial dowry inflation in these countries (Rao 1993, Amin and Cain 1997, Anderson 2003, Esteve-Volart 2004) $3^{3}$ Though there is no systematic data on dowry related violence and death, it is estimated that more than 200 women are being killed every year in Bangladesh due to dowry related violence 4 Sekhri and Storeygard (2014) report that in India, on average, 12.1 women die per district per year due to dowry, and the trend, if anything, is increasing over time. Similarly, mehr, which is enshrined in Islamic law, continues to flourish in Muslim societies (Amin and Cain 1997).

A stylized fact about mehr and dowry in Bangladesh is that both have experienced large fluctuations since the 1960s (see Section 5). Further, Bangladesh has experienced three major economic (and political) shocks since the 1960s. These are: (i) the introduction of new agricultural technologies in the 1960s, popularly known as the Green Revolution (GR), (ii) the war of independence of 1971 (IW), and (iii) the famine of 1974. The adoption of new technology during the GR period acted as a positive income shock. In particular, given the nature of the technological change, the GR had a positive effect on labor income. In contrast, the IW and the famine both acted as negative income shocks.

Our central thesis is that there is a causal link between these income shocks, and the changes

\footnotetext{
${ }^{1}$ While Islamic law prescribes that mehr be paid on the consummation of marriage, the practice is different in Bangladesh and the Indian subcontinent. Ambrus et al. (2010) conjecture that the difference is because polygamy was not feasible for all but the richest, and that men had unilateral right to divorce.

${ }^{2}$ Anderson (2007, Tables 2 and 4) and Anderson and Bidner (2015) document that the dowry system goes back to the ancient Greco-Roman world, and was prevalent in the middle ages. Further, it continued to be widespread during the Renaissance and early modern Europe, and currently in South Asia.

${ }^{3}$ Anderson and Bidner (2015) state that in Bangladesh "the total cash and goods involved are often so large that the transfer can involve impoverishment of the bridal family." Similar points have been made by Rao 1993 , and Huda 2006, among others.

${ }^{4}$ See http://khabarsouthasia.com/en_GB/articles/apwi/articles/features/2012/02/15/feature-02.
} 
in dowry and mehr. In tracing a link between the economic aspects of marriages and marriage market institutions, we follow Becker $(1973,1981)$ and Cherchye et al. (2017) who argue that gains from marriages play a critical role in understanding marriage markets, with such gains depending on particular unions, as well as the marriage market as a whole. While Cherchye et al. (2017) demonstrate that outside options play a critical role in deciding the share of household resources obtained by a spouse, Cherchye et al. (2016) establish their effect on divorce probabilities as well. Our paper extends this idea to other aspects of the marriage market, in particular dowry and mehr.

We first develop a model of marriage markets that respects institutional realities, in particular we consider societies where norms and institutions favor men. One aspect of this bias is that in the event a marriage is not successful (in a sense formalized later), the decision to divorce, if any, is taken by men.5 Consequently, men may opt to divorce their wives even though the aggregate surplus of the couple would be higher if they stayed married rather than obtained a divorce. It is this possibility of inefficient divorce that creates a role for mehr, in that mehr is a cost which men have to incur in the event of a divorce, thus discouraging such divorces. Given that the divorce decision is taken by men, mehr thus equals the utility of men from divorce net of their utility from continuing in a marriage that is 'average' (i.e. neither a success, nor a failure as formalised later). Dowry plays the role of a groom price, ensuring that the marriage market clears. It therefore equals the utility of men from remaining unmarried net of their ex ante utility from marriage. Along the equilibrium path, divorce happens if and only if it is efficient, and moreover, mehr payments are made in case the marriage is a failure.

Turning to the effect of various income shocks, we demonstrate that a positive income shock, e.g. the GR, would lead to an increase in mehr. With social norms being biased in the favour of men, divorce does not impose too much of a cost on men (in a sense formalized later), so that an increase in the income of men increases their utility from a divorce to a greater extent relative to that from an average marriage, making divorce relatively more attractive. Hence the level of mehr must increase so as to prevent inefficient divorces in such marriages. Similarly, the famine and the IW can both be interpreted as negative income shocks, thereby making divorce less attractive. Hence, these would lead to a decline in mehr.

The effect of an income shock on dowry is similar to than on mehr; although the former would be of a smaller magnitude, the rate of change in both dowry and mehr would be the same. The result is intuitive. Dowry equals the utility of men from remaining unmarried net of the opportunity cost of doing so, whereas mehr equals the utility from divorce in a failed marriage net of the corresponding opportunity cost. The opportunity cost of remaining single is however larger since it factors in the possibility that a marriage may be successful or a failure.

\footnotetext{
${ }^{5}$ According to the Shari'a, a husband may unilaterally divorce his wife (Brandt and Kaplan 1995-1996), a belief that persists widely among Muslims and is practiced in India (Vatuk 2008), as well as Bangladesh and Pakistan (Carroll 1986b).
} 
Given the concavity of the natural log function, this in turn ensures that the rate of change would be the same for dowry and mehr.

We next consider several extensions of the baseline framework as robustness checks. Allowing for the fact that in patriarchal societies men may have property rights over the income of their wives (see Anderson and Bidner 2015), we show that income shocks are positively correlated with mehr as long as their effects on men and women are not too dissimilar, and would cause the same rate of change in mehr and dowry. We also extend the analysis to allow for income heterogeneity among men and women. We show that an equilibrium with positive assortative matching exists, where all the comparative statics predictions go through. Finally, we consider a setup where dowry is set via bargaining between groom and bride families. Under some additional conditions, the comparative statics results also go through qualitatively.

To take the model predictions to the data, we exploit several natural experiments, namely the GR of the 1960s, the IW, and the famine in the 1970s, where we club the IW and famine together and treat these as a single negative income shock. We use two distinct household data sets collected in 2004-2005 and 2010-2011 in Bangladesh. For identification purposes we rely on pre-post comparisons to argue that income shocks have a causal effect on mehr and dowry. We find that the value of (log) mehr increased significantly during the GR period (1961-1970) vis-á-vis the previous period. However, although the value of $(\log )$ dowry increased over the same time span, its coefficient is not statistically significant. Turning to the post famine period, we find that both $(\log )$ mehr and (log) dowry decreased. In all cases, the differences in the rate of change between mehr and dowry are not statistically significant.

To check the robustness of our results, we analyze a third data set from the Indian state of West Bengal that is similar to Bangladesh in many respects and also experienced an increase in agricultural productivity (which we call the GR) at the same time. We find that patterns of fluctuations in the values of dowry and mehr in the GR period are the same in both Bangladesh and West Bengal. It is important to mention that over the period 1960-2000, there were several legal changes in Bangladesh aimed at restricting polygamy and curbing the practice of dowry. Two of these legal changes namely the Muslim Family Law Ordinance of 1961 (MFLO), and the Registration of Muslim Marriages and Divorces Act of 1974 (MMDA) coincided with the advent of the GR and the occurrence of the famine, respectively. In contrast, there were no such legal changes in West Bengal as being a part of India. Therefore, the fact that mehr and dowry showed very similar patterns in Bangladesh and West Bengal are attributed to the positive economic shocks, rather than legal changes. This conclusion finds further support from the existing literature ${ }^{6}$ Finally, we examine if the increased mehr in the 1960s was a result of "missing women" caused by sex-selective abortion, female infanticide and neglect of female

\footnotetext{
${ }^{6}$ Esteve-Volart (2004) used a rural household survey conducted in one sub-district of Bangladesh (Matlab Health and Socio Economic Survey) and found no effect of the MMDA on the amount of dowry in Muslim marriages in the post-1974 period (Esteve-Volart 2004, Table 5).
} 
children (Sen 1990).

To the best of our knowledge, this is the first paper in the literature that establishes the effects of natural shocks on the levels of mehr and dowry. In addition, our paper stands distinctively in the marriage market literature in several respects. The extant literature on marriage market transactions has mostly focused on dowry in assuming a competitive marriage market where dowry acts as a market-clearing price (Cole, Mailath and Postelwaite 2001, Peters and Siow 2002, and Anderson and Bidner 2015) 7 While we also assume a competitive marriage market, our paper differs significantly from this strand of literature by considering a framework with both dowry and mehr. We show that mehr can play an important role in ensuring the efficiency of the marriage market. It is somewhat surprising that despite its universal practice in Muslim marriages, the institution of mehr has not received adequate attention in the literature.

One paper that analyzes a framework with both dowry and mehr is Ambrus et al. (2010), but they focus on the effects of legal changes rather than income shocks, so that their paper is complementary to ours. These authors argue that dowry and mehr co-move but does not analyze the relative magnitude of changes in their values caused by legal changes, while we show that mehr is more responsive to income shocks relative to dowry, though the rate of change is the same 8

Another related paper is Anderson and Bidner (2015) who model two marriage market institutions - dowry and parental investment in children (i.e. bequests). Their formulation however does not allow for divorce. Moreover, while our extended model incorporates some elements of Anderson and Bidner (2015), to be precise men's property rights over spousal income, our results are not driven by it.

The rest of the paper proceeds as follows. In Section 2 we describe the economic and political shocks that Bangladesh had experienced since the 1960s. In Section 3 we present our theoretical framework, deriving some testable implications of the analysis. In Section 4 we extend the model in several dimensions. Next in Section 5, we discuss the datasets and some key descriptive statistics. The identification and the estimation strategies are explained in Section 6. In Section 7 we present our main empirical findings, and in Section 8 we rule out alternative explanations such as legal changes. Finally, we conclude in Section 9.

\section{Natural Shocks During the 1960s and 1970s}

\subsection{Income shocks}

Since the 1960s Bangladesh has experienced several exogenous economic (and political) shocks, with the Green Revolution (GR) being one of the most significant. Beginning in 1959, the then East Pakistan government adopted several new technologies, as well as policies favoring

\footnotetext{
${ }^{7}$ Some earlier papers that include Becker (1981) and Rao (1993) also assume dowry as a groom price.

${ }^{8}$ See Appendix 3 for a more detailed discussion of the empirical results in Ambrus et al. (2010).
} 
the agricultural sector. Under the Grow More Food program started in 1959, the government introduced chemical fertilizers (Hossain et al. 1994) and mechanized irrigation at heavily subsidized rates (Falcon and Gotsch 1970). These inputs became readily and widely available in the early 1960s; over the 1961-70 period, the disbursement of chemical fertilizers increased by $35.5 \%$ per annum (Khan, 1972, Table 5.8, p. 50). Other technological innovations include the introduction of pesticides, improved local seed varieties, and a shift to the Japanese Method of rice cultivation, which involved a series of labor-intensive operations (Falcon and Gotsch 1970, pp. 270, 288-298).

The adoption of these new technologies led to substantial increase in agricultural productivity. During the 1961-70 period, both East and West Pakistan experienced unprecedented growth in agriculture and rural private investment. The annual agricultural growth rate nearly tripled, increasing from 1.2 percent to 3.2 percent. In Bangladesh (the then East Pakistan), the agricultural sector grew at 3 percent per annum on average over this period. Rice, which contributed 70 percent of the value added of all crops, grew at 3.4 percent per annum, and Boro rice, which was a prime consumer of modern inputs, notably grew at 6.2 percent per annum (Falcon and Gotsch, 1970, Table 9.12, p. 293, Table 9.13, p. 295). These technologies increased the demand for labor and consequently wages 9

We consider 1961 as the commencement of the Green Revolution, as this is the earliest period of documented increase in agricultural income, although our results, presented in Section 7, are robust to the choice of alternative commencement date. In particular the analysis goes through qualitatively if we take the starting point to be 1967, 10 when the high yielding variety (HYV) seeds were introduced (David and Otsuka 1994).

A second major event was the Independence War (IW), which broke out abruptly in March 1971 and ended in December 1971 with the birth of a new nation (Bangladesh). The war was extremely costly on several dimensions, most importantly in terms of lives lost, with a loss of 2 to 3 million civilian lives (Riedel 2011). Further, approximately 10 million people were forced to take refuge in neighboring India, with most of them completing their resettlement in Bangladesh only by the end of 1973 . In addition, the war devastated the economy; GDP declined by $5.6 \%$ in 1971 and by 15\% in 1972 (Appendix 2, Figure A1b). The independence war was clearly a large negative income shock.

Soon after the war and resettlement of refugees, the country was hit by another major negative shock, this time a devastating famine in 1974 that disproportionately affected the rural population. Following this famine, GDP declined by more than 5 percent in 1975 . Taken together, the IW and the famine were not only major negative income shocks, the effects persisted for quite some time with GDP returning to its pre-war level only in 1977 (Appendix 2, Figure

\footnotetext{
${ }^{9} \mathrm{GR}$ had a large positive effect on wages, especially for male. Using village-level daily wage data from India, D'Agostino (2017) finds that GR generated a 7 percent wage increase for male laborers in the 1960s and 1970s. Women substituted away from wage work, and increased their unpaid own-farm work and home production.

${ }^{10}$ The results are available upon request.
} 
A1a).

\subsection{Legal shocks}

Between 1961 and 2004, Bangladesh witnessed five legal amendments to Muslim family laws governing marriage, dowry and divorce, as well as case law developments pertaining to these. These include (i) the Muslim Family Law Ordinance (MFLO) of 1961, (ii) the Registration of Muslim Marriages and Divorces Act (MMDA) of 1974, (iii) the Dowry Prohibition Act of 1980 and Dowry Prohibition (Amendment) Ordinances of 1982, 1984 and 1986, (iv) Case Law Development in 1990 (Rustom Ali v. Jamila Khatun) and a Supreme Court verdict in 1998, and (v) the Women and Children Repression Prevention Act of 2000. Note that the first legal change, i.e. the MFLO in 1961, coincided with GR, and the second legal change, i.e. the MMDA in 1974, coincided with the famine.

Briefly, the main objective of the MFLO, which became effective in Bangladesh (then Pakistan) in $1963{ }^{11}$ was to restrict polygamy and arbitrary divorce. To that end it imposed the requirement that, in case of second marriage, a husband has to obtain the consent of his first wife, as well as written permission of the local government authorities at the residence of the second wife. The main objective of the MMDA was to further restrict polygamy and arbitrary divorce by making marriage registrars widely available ${ }^{12}$ The main objective of the Dowry Prohibition Act and subsequent amendments in the 1980s was to reduce dowry by making both the giving and receiving of dowry illegal ${ }^{13}$ Anti-dowry laws were further strengthened by the Women and Children Repression Prevention Act of 2000, which mandated the imposition of the maximum possible punishment for dowry related violence and death.

The two case law developments of 1990 and 1998 went against the Malik 14 interpretations of alimony obligations specified in the MFLO. In 1990, in Rustom Ali v. Jamila Khatun, 43 DLR (1991) 301, the High Court ruled that a former wife may not claim alimony unless the parties have a previously established agreement. In 1998, the Supreme Court upheld the 1990 ruling on alimony.

\section{The Framework}

We consider an economy that comprises two kinds of families, one of these having a potential groom each, and the other having a potential bride each. The mass of families with a potential

\footnotetext{
${ }^{11}$ See http://bdlaws.minlaw.gov.bd/print_fections_all.php?id=305 accessed February 29, 2012.

${ }^{12}$ See http://bdlaws.minlaw.gov.bd/print_fections_all.php?id=476, accessed on February 29, 2012.

13 http://bdlaws.minlaw.gov.bd/sections_detail.php?id=607\&sections_id=10780\&vol=22 accessed on February 29, 2012.

${ }^{14}$ Maliki is one of four prominent schools of religious law within Sunni Islam, the dominant interpretation among the Muslims in Bangladesh.
} 
groom is 1 , whereas the mass of families with a potential bride is $N$, where $N \leq 1.15$ For simplicity we assume that all agents are risk neutral. ${ }^{16}$ Moreover, all men are identical, as are all women, with all men having the same income $m$, and all women having the same income $w$. The two income measures $m$ and $w$ encapsulate several elements that are important in the context of marriages, including not just the economic potentials of men and women, but also their personal characteristics like age, beauty, educational qualifications, etc. In the event of a marriage, a woman (respectively man) brings her income $w$ (respectively his income $m$ ) to the marriage.

Once a marriage takes place, it turns out to be one of three kinds, successful, failed, and average, with probabilities $\gamma_{s}, \gamma_{f}$ and $\gamma_{a}$ respectively, where $0<\gamma_{s}, \gamma_{f}, \gamma_{a}<1$ and $\gamma_{s}+\gamma_{f}+\gamma_{a}=$ 1. A successful marriage has a positive effect on the aggregate surplus of the couple, denoted $S[w+m]$, in that $S>1 .{ }^{17}$ Whereas the surplus is $t_{f}[w+m]$ in case the marriage fails, and $t_{a}[w+m]$ when the marriage is average, where $t_{f}<t_{a} \leq 1{ }^{18}$ In these societies marriage is the social norm, so that relative to a successful marriage, men and women who either get divorced, or decide not to participate in the marriage market at all, do worse 19 Under either eventuality, a man has a utility of $\mu_{m} m$, and a woman has a utility of $\mu_{w} w$, where $S>\mu_{m}, \mu_{w}$.

Consistent with the bias in favour of men, we assume that it is men who take the divorce decision 20 Moreover, either being divorced or remaining single is relatively costlier for women, i.e. $\mu_{m}>\mu_{w}{ }^{21}$ In what follows, we maintain the following parametric condition (that also incorporates some of the preceding considerations),

$$
S>\mu_{m}>t_{a}>t_{f}>\mu_{w},
$$

that is a necessary condition for both mehr and dowry to be positive in equilibrium, as we shall later argue ${ }^{22}$ Moreover, getting divorced is inefficient in case a marriage is average, whereas it

\footnotetext{
15 The assumption that there are more men than women is realistic for many developing countries, including those countries that we study. In our data for Bangladesh, $99 \%$ of women get married between age 10 and age 25 and $95 \%$ of men get married between age 15 and age 35 . The total number of male divided by the total female in these age brackets always remains higher than 1 since 1951 (varied between 1.08 and 1.24). See Appendix 2, Table A5.

${ }^{16}$ Assuming risk neutrality simplifies the exposition by abstracting from issues of insurance. It is straightforward to argue that the analysis goes through as long as the agents are not too risk averse. See Remark 8 later.

${ }^{17}$ Browning et al. (2014) argue that such gains can be traced to sharing of public goods, or division of labour within a marriage, among other things.

${ }^{18}$ Later we extend the framework in various directions, finding that this does not affect the results qualitatively. In Remark 9 we allow for income heterogeneity among men and women, arguing that this would lead to positive assortative matching. Further, in Section 4 we allow for a scenario where men have property rights over their spouse's income.

${ }^{19}$ Borker et al. (2017) assume that in the Indian context the social norm is that all women must marry.

${ }^{20}$ For example, see Brandt and Kaplan (1995 - 1996), who discuss husbands' rights to divorce their wives among Muslims in Bangladesh, as well as Egypt and Tunisia.

${ }^{21}$ Divorced women in Bangladesh and other South Asian countries are socially stigmatized, and are not accorded a status equal to that of married women (Dreze and Sen 1995, Esteve-Volart 2004).

${ }^{22}$ It is straightforward to see that if, instead $\mu_{m}, \mu_{w}>t_{a}$, then 2 does not hold, so that even in case of
} 
is efficient in case the marriage is a failure; formally,

$$
t_{f}[w+m]<w \mu_{w}+m \mu_{m}<t_{a}[w+m] .
$$

Given that men take the divorce decision, it is however possible that in certain situations men may, in their own interest, decide to divorce their spouses even though doing so is inefficient. We shall argue that it is the possibility of such inefficient divorces that creates a role for mehr.

Marriage contracts potentially involve two kinds of transfers, dowry (denoted by $D$ ), which is an upfront payment from a woman's family to the groom, and mehr (denoted dy $M$ ), which is a conditional payment made by a man's family to the bride in the event of a divorce. Given a marriage contract $(D, M)$ we can now specify the utility functions of men and women. The utility of a man equals

$$
u^{M}=\left\{\begin{array}{l}
S m+D, \text { if the marriage is successful and there is no divorce, } \\
t_{f} m+D, \text { if the marriage has failed but there is no divorce, } \\
t_{a} m+D, \text { if the marriage is average but there is no divorce, } \\
\mu_{m} m+D-M, \text { if there is divorce, } \\
\mu_{m} m, \text { if the man remains single. }
\end{array}\right.
$$

Similarly the utility of a woman is given by

$$
u^{W}=\left\{\begin{array}{l}
S w-D, \text { if the marriage is successful and there is no divorce, } \\
t_{f} w-D, \text { if the marriage has failed and there is no divorce, } \\
t_{a} w-D, \text { if the marriage is average but there is no divorce } \\
\mu_{w} w-D+M, \text { if there is divorce, } \\
\mu_{w} w, \text { if the woman remains single. }
\end{array}\right.
$$

We next turn to defining a notion of equilibrium for this society, where we shall only be concerned with the utilities of the brides and the grooms themselves. In reality, other considerations, e.g. the potential gain in status to the concerned families, can be expected to enter these negotiations. Anderson and Bidner (2015), for example, consider the utility of the parents as well. Borker at al. (2017), on the other hand, assume that the wealth level of the families is an important consideration. We, however, abstract from such considerations.

We follow Rosen (1974), Peters and Siow (2002), Anderson and Bidner (2015), among others, in modelling marriage market equilibrium competitively ${ }^{23}$ The equilibrium 'price', denoted $\left(D^{*}, M^{*}\right)$, comprises both dowry and mehr. A woman's strategy is optimal with respect to $\left(D^{*}, M^{*}\right)$ if she participates in the marriage market if and only if doing so yields a higher utility relative to not participating. Similarly a man's strategy is optimal with respect to $\left(D^{*}, M^{*}\right)$ if

an average marriage divorce is efficient and there is no scope for mehr in our framework. Whereas if, instead, $t_{a}>\mu_{w}, \mu_{m}$, then $(9)$ does not hold and dowry cannot be positive.

${ }^{23}$ In a comment in Section 4 we briefly consider a framework where dowry is determined by bargaining between bride and groom families, arguing that the results are qualitatively similar. 
(i) he participates in the marriage market if and only if doing so yields a higher utility relative to not participating, and, (ii) he opts to divorce his wife if and only if doing so yields him a higher utility.

Let $P_{M}\left(D^{*}, M^{*}\right)$ denote the number of men, and $P_{W}\left(D^{*}, M^{*}\right)$ denote the number of women participating in the marriage market, with the strategies of all agents being optimal given $\left(D^{*}, M^{*}\right)$.

We are now in a position to formally define the notion of an equilibrium.

Definition 1 A marriage market pricing rule $\left(D^{*}, M^{*}\right)$ is an equilibrium if and only if the number of participating men and women are equal, i.e. $P_{M}\left(D^{*}, M^{*}\right)=P_{W}\left(D^{*}, M^{*}\right)$.

We are interested in equilibria that satisfies some additional properties, in particular that of efficiency.

Definition 2 An equilibrium $\left(D^{*}, M^{*}\right)$ is said to be efficient if and only if (a) the outcome involves no inefficient divorce and (b) for any man and woman, the aggregate ex ante surplus from marriage (followed by divorce if that is efficient) exceeds that from remaining single.

Turning to condition (a), when is divorce inefficient? Under a successful, as well as a average marriage, the surplus from marriage exceeds the surplus from divorce, i.e. $S[m+w]>t_{a}[m+w]>$ $\mu_{m} m+\mu_{w} w$, so that divorce is inefficient (see (2)). Divorce is however efficient in case of a failed marriage since $t_{f}[m+w]<\mu_{m} m+\mu_{w} w$ (see (2)). Turning to condition (b), note that the aggregate ex ante surplus from marriage (followed by divorce in case the marriage fails), i.e. $\gamma_{s} S[m+w]+\gamma_{f}\left[m \mu_{m}+w \mu_{w}\right]+\gamma_{a} t_{a}[m+w]$, exceeds that from remaining single, i.e. $\mu_{m} m+\mu_{w} w .{ }^{24}$ Thus efficiency demands that all women get married 25

We shall focus on equilibria that are not only efficient, but moreover the level of mehr $M^{*}$ is at the minimum possible level consistent with efficiency. As we shall later find, doing so ensures that there is partial consumption smoothing for men, in that their utility from average and failed marriages are the same. Given the reality that the social norms favour men, it is therefore natural to focus on this level of mehr. ${ }^{26}$ For ease of exposition we shall henceforth refer to efficient equilibria satisfying the minimal condition on mehr simply as equilibria.

Turning to the analysis of the equilibrium, divorce never takes place in case the marriage is a successful one, since the man's payoff from a stable marriage exceeds that in case of a divorce, i.e.

$$
S m+D>\mu_{m} m+D-M .
$$

\footnotetext{
${ }^{24}$ The result follows since, $S[m+w]>t_{a}[m+w]>\mu_{m} m+\mu_{w} w$ where the second inequality follows from 22.

${ }^{25}$ In Remark 4 later we provide a non-cooperative foundation for our focus on efficient equilibria.

${ }^{26}$ For the consumption smoothing argument to bite, one has to allow for risk aversion. Formally, one can start with a framework where the agents are risk averse. Then, in the limit, taking the extent of risk aversion among men to zero, the fact that mehr is set at the minimal level that prevents inefficient divorce emerges as a result, rather than as an assumption.
} 
However, depending on $(D, M)$, divorce may happen in case the marriage is either average, or if it fails. In particular divorce happens if and only if $t_{i} m+D<\mu_{m} m-M+D, t_{i} \in\left\{t_{f}, t_{a}\right\}$, i.e. if the mehr is small

$$
M<m\left[\mu_{m}-t_{i}\right] .
$$

Equation (6) shows that divorce decisions are not affected by the level of dowry at all. Thus, it must be mehr which ensures that there is no inefficient divorce 27

We next solve for the equilibrium level of mehr. Recall that in the absence of mehr divorce happens both when the marriage is average, as well as when it is a failure, whereas divorce is efficient if and only if the marriage fails. From (6), the minimal level of mehr that prevents divorce in an average marriage

$$
M^{*}=m\left[\mu_{m}-t_{a}\right]
$$

Further, for a mehr of $M^{*}$, divorce does happen in case the marriage fails (since $t_{f} m+D<$ $\mu_{m} m-M^{*}+D$, given that $t_{a}>t_{f}$ ), whereas divorce never happens happens in a successful marriage. Proposition 1 below summarizes the preceding discussion.

Proposition 1 The equilibrium level of mehr $M^{*}$ ensures that divorce happens if and only if doing so is efficient, i.e. if the marriage is a failure. There is no divorce otherwise. Moreover, mehr payments happen in equilibrium, in particular in case of a failed marriage.

We next turn to solving for the equilibrium dowry. Let $D^{*}$ denote a level of dowry such that men are indifferent between remaining single, and getting married. From Proposition 1, recall that there is divorce if and only if the marriage is a failure. Moreover, in that event the utility of the concerned man is given by $\mu_{m} m-M^{*}=t_{a} m$. Consequently, $D^{*}$ must satisfy $\mu_{m} m=\gamma_{s} S m+\gamma_{f} t_{a} m+\gamma_{a} t_{a} m+D^{*}$, so that

$$
D^{*}=m\left[\mu_{m}-\gamma_{s} S-\left(1-\gamma_{s}\right) t_{a}\right]
$$

$D^{*}$ is positive whenever men are not too badly off in the event of remaining single; formally,

$$
\mu_{m}>\gamma_{s} S+\left(1-\gamma_{s}\right) t_{a}
$$

Since dowry is positive and increasing for these societies over the relevant period (as discussed earlier in the introduction), in what follows we assume that (9) holds. Our comparative statics predictions in Propositions 5 and 6 that we take to the data however do not depend on (9) at all.

It is straightforward to see that $\left(D^{*}, M^{*}\right)$ constitutes an equilibrium. We first argue that all women participate in the marriage market.

\footnotetext{
${ }^{27}$ Consider a marriage that has either failed, or is average. Given the preceding discussion, it is clear that in the absence of mehr, the outcome will involve divorce (since $\left.\mu_{m}>t_{i}, i=1,2\right)$. Moreover, given 2 such a divorce will be inefficient.
} 
Lemma 2 Given $\left(D^{*}, M^{*}\right)$, a woman's utility from participating in the marriage market exceeds that from not participating.

Proof. It is sufficient to argue that all women prefer to get married, rather than remain single. From Proposition 1, the equilibrium level of mehr ensures that divorce happens if and only if the marriage fails. Consequently women's utility from participation equals $\gamma_{s} S w+\gamma_{f}\left[w \mu_{w}+M^{*}\right]+$ $\gamma_{a} t_{a} w-D^{*}=\gamma_{s} S w+\gamma_{f}\left[w \mu_{w}+m\left(\mu_{m}-t_{a}\right)\right]+\gamma_{a} t_{a} w-m\left[\mu_{m}-\gamma_{s} S-\left(1-\gamma_{s}\right) t_{a}\right]$. This exceeds the women's utility from remaining single, i.e. $w \mu_{w}$, if and only if $\gamma_{s} S(w+m)+\gamma_{f}\left(w \mu_{w}+m \mu_{m}\right)+$ $\gamma_{a} t_{a}(w+m)>m \mu_{m}+w \mu_{w}$, i.e. if and only if the ex ante surplus from marriage (allowing for efficient divorce if the marriage is a failure) exceeds the surplus from remaining single. This is true given (1).

Thus all women enter and $P_{W}\left(D^{*}, M^{*}\right)=N$. Whereas given $\left(D^{*}, M^{*}\right)$ men are indifferent between staying single and entering the marriage market. Thus $\left(D^{*}, M^{*}\right)$, where (i) $M^{*}$ is set to satisfy Proposition 1, (ii) $D^{*}$ satisfies (8), (iii) all women and a fraction $N$ of the men participate in the market, and (iv) men take the divorce decision optimally, constitutes an equilibrium. ${ }^{28}$

Proposition 3 below summarizes the preceding discussion.

Proposition 3 There is an equilibrium $\left(D^{*}, M^{*}\right)$ where $M^{*}$ is set at the minimum level that prevents inefficient divorce, and the dowry $D^{*}$ ensures that men are indifferent between entering the marriage market and remaining single. For $N<1,\left(D^{*}, M^{*}\right)$ is the unique equilibrium.

Proof. Let $N<1$. Clearly, in any (efficient) equilibrium, the amount of mehr must equal $M^{*}$. If the dowry exceeds $D^{*}$, then all men participate, while at most $N$ women do, so that the marriage market cannot clear given that $N<1$. Whereas if the dowry is less than $D^{*}$, then no man participates, while all women do.

At this point we briefly examine an alternative two stage game such that there exists a subgame perfect Nash equilibrium of this game that coincides with that described above. Thus in this game efficiency follows as a result, rather than being an assumption.

Remark 4 Consider a two stage game where, in stage 1, all men simultaneously make anonymous marriage offers, with the $i$-th man making an offer of $\left(D_{i}, M_{i}\right)$, and in stage 2 , the women sequentially decide which one of the remaining offers to accept, if at all. We look for subgame perfect Nash equilibria (spNe) of this game, arguing that the outcome where all men make an offer of $\left(D^{*}, M^{*}\right)$ in stage 1 can be sustained as a spNe. Clearly, in stage 2, any woman considers

\footnotetext{
${ }^{28} \mathrm{It}$ is clear that there can be inefficient equilibria where mehr is either absent, or not sufficiently large to prevent inefficient divorce. There are countries where Muslim marriages do not involve a mehr which is conditional on divorce. For simplicity let the mehr be zero. It is then straightforward to check that the equilibrium dowry would be negative. This possibility perhaps an artifact of the present simple framework, but this result does suggest that dowry is likely to be lower in societies where there is no mehr.
} 
the set of offers still on the table, accepting one that yields her the highest utility (breaking ties randomly), as long as there is one offer that yields her at least $\mu_{w} w$. Otherwise, she rejects all offers. We then argue that given that every man offers $\left(D^{*}, M^{*}\right)$, no man has an incentive to deviate from $\left(D^{*}, M^{*}\right)$. Note that $\left(D^{*}, M^{*}\right)$ maximizes the aggregate expected surplus from any marriage since a mehr of $M^{*}$ ensures that divorce happens if and only if it is efficient. Consequently under any deviant offer $\left(D^{\prime}, M^{\prime}\right)$, the aggregate surplus cannot be any higher, whereas for this offer to be acceptable to women they must be offered at least as much utility as they obtain under $\left(D^{*}, M^{*}\right)$. Hence the utility of the concerned man cannot be any higher relative to what he would obtain under $\left(D^{*}, M^{*}\right)$.

Example. In order to establish that the various assumptions are mutually consistent, consider an example where $S=2, t_{a}=0.6, \quad t_{f}=0.4, \quad \mu_{m}=1, \quad \mu_{w}=0, \quad \gamma_{s}=0.25$ and $w=m>0$. These parameter values satisfy the constraints (1), (2) and (9). Moreover, mehr and dowry are positive and women prefer to participate in the marriage market rather than remain single.

\subsection{Exogenous shocks: Income and legal}

We next turn to developing some testable implications of this framework that we can take to data. To that end we examine the impact of income shocks on both equilibrium values of mehr and dowry. We also examine the impact of legal changes as some of these coincided with income shocks.

\subsubsection{Income shocks}

As discussed in Section 2, in the context of Bangladesh, the Green Revolution that happened in the 1960s can be interpreted as a positive, whereas the Independence War of 1971 and the 1974 famine can be interpreted as negative income shocks.

From (7), it is straightforward to show that the level of mehr is increasing in $m$.

Proposition 5 Consider the effect of income shocks. The equilibrium level of mehr $M^{*}$ increases in case the shock is a positive one, and decreases otherwise.

Proposition 5 is intuitive. Recall that the role of mehr is to prevent inefficient divorces in case of an average marriage. Given that the divorce decision is taken by men, mehr equals the utility of men from getting a divorce net of their utility from continuing in an average marriage. While a positive income shock, in particular an increase in $m$, increases the utility of a man both in the event of his getting a divorce, as well as continuing in an average marriage, there is a greater increase in utility in the former than in the latter event. Thus in the event of a positive income shock, the incentive to divorce increases, necessitating an increase in mehr as well. 
Turning to the effect of income shocks on dowry, it is straightforward to check that

$$
\frac{d D^{*}}{d m}=\mu_{m}-\gamma_{s} S-(1-\gamma) t_{a}<\mu_{m}-t_{a}=\frac{d M^{*}}{d m} .
$$

Since the opportunity cost of remaining single, i.e. a man's ex ante utility from getting married, exceeds the opportunity cost of a divorce in an average marriage, i.e. a man's utility from continuing in such a marriage, intuitively the result follows.

Finally, income shocks generate the same rate of change in mehr and dowry as shown by:

$$
\frac{d \log D^{*}}{d m}=\frac{1}{m}=\frac{d \log M^{*}}{d m} .
$$

Proposition 6 Both the level of dowry and mehr increase in positive income shock and they increase at the same rate.

Propositions 5 and 6 together suggest the following testable hypotheses: both the dowry and mehr will increase during the Green Revolution in Bangladesh as well as in India, and decrease during the Independence War and famine in Bangladesh.

\subsubsection{Legal shocks}

During the period under consideration, there were several changes in Muslim personal law, in particular the Muslim Family Law Ordinance of 1961 (MFLO) and the Registration of Muslim Marriages and Divorces Act of 1974 (MMDA). Importantly, the MFLO occurred around the same period as the GR, and the MMDA occurred around the same time as the famine. Given these legal changes, we then ask if the observed changes in mehr and dowry during this period could be attributed to these legal changes instead.

We shall use the following properties of $D^{*}$ and $M^{*}$ in the subsequent analyses. The proof, which is straightforward, has been omitted.

\section{Observation 1.}

(i) $M^{*}$ does not depend on $S$, but is decreasing in $t_{a}$.

(ii) $D^{*}$ is decreasing in both $S$ and $t_{a}$.

(iii) $D^{*}$ and $M^{*}$ are both increasing in $\mu_{m}$.

Given that mehr plays a role only if a marriage fails, it is intuitive that $S$ does not affect the level of mehr, while $t_{a}$ does. $D^{*}$ takes the ex ante utility from marriage into account, so that both $S$ and $t_{a}$ are relevant.

As discussed in the section 2.2 , the MFLO was aimed at restricting polygamy 29 In our framework this can be expected to increase the utility from the first marriage, both successful

\footnotetext{
${ }^{29}$ While restrictions were imposed on arbitrary divorce as well, these may not have been very effective in the absence of penalties for failure to comply, or explicit specification of maintenance payments.
} 
as well as failed, so that $S$ and $t_{a}$ should both increase. Thus from Observation 1 both mehr and dowry decrease.

The MMDA was aimed at reducing arbitrary divorces, which can be formalized as a reduction in $\mu_{m}$, since a decline in $\mu_{m}$ makes divorce less attractive. Another objective was to reduce polygamy, which can be expected to increase both $S$ and $t_{a}$. From Observation 1, it is again straightforward that both mehr and dowry decrease.

Further, we examine if, similar to what we observe in case of income shocks (Proposition 4), legal shocks have a smaller absolute effect on dowry, relative to that on mehr. We consider a benchmark case where both the MMDA and MFLO affect $S, t_{a}$, and $t_{f}$ to the same extent, so that $d S=d t_{a}=d t_{f}$. It is then straightforward to see that,

$$
\begin{aligned}
\frac{d D^{*}}{d t_{a}} & =-m=\frac{d M^{*}}{d t_{a}}, \\
\text { and, } \frac{d D^{*}}{d \mu_{m}} & =m=\frac{d M^{*}}{d \mu_{m}},
\end{aligned}
$$

so that the MFLO and the MMDA have the same magnitude of effects on both dowry and mehr.

Proposition 7 Consider the impact of the MFLO and the MMDA.

(i) Following the implementation of the MFLO, formalized as an increase in $S, t_{a}$, and $t_{f}$, both mehr and dowry decrease.

(ii) Following the implementation of the $M M D A$, formalized as a decrease in $\mu_{m}$, as well as an increase in $S, t_{a}$, and $t_{f}$, both mehr and dowry will decrease.

(iii) Following either the MFLO or the MMDA, dowry and mehr change by the same magnitude.

Thus our framework predicts that, ceteris paribus, both the MFLO and the MMDA would affect dowry and mehr in a similar fashion. In particular, the immediate effect of the MFLO would be to reduce the level of mehr and dowry, which is contrary to the empirical realities in Bangladesh. The predictions from the MMDA are, however, consistent with the changes in mehr and dowry during this period. Consequently, we argue that changes in mehr and dowry cannot be attributed to legal changes.

We then extend the framework in several directions. While in Remark 8 we allow for risk averse agents, in Remark 9 we allow for income heterogeneity among both men and women. We find that our comparative statics predictions go through under all these extensions.

Remark 8 Let the utility function of men be $u_{m}($.$) , and that of women be u_{w}($.$) , where both$ $u_{m}($.$) and u_{w}($.$) are concave. It is straightforward to check that the equilibrium mehr solves$ $u_{m}\left(m \mu_{m}\right)=u_{m}\left(t_{a} m-M^{*}\right)$, so that it remains unchanged at $M^{*}=m\left(\mu_{m}-t_{a}\right)$. The equilibrium dowry $D^{*}$ solves

$$
u_{m}\left(\mu_{m} m\right)=\gamma u\left(S m+D^{*}\right)+\left(1-\gamma_{s}\right) u\left(t_{a} m+D^{*}\right)
$$


Consequently,

$$
\frac{d D^{*}}{d m}=\frac{\mu_{m} u^{\prime}\left(\mu_{m} m\right)-\gamma_{s} S u^{\prime}\left(S m+D^{*}\right)-\left(1-\gamma_{s}\right) t_{a} u^{\prime}\left(t_{a} m+D^{*}\right)}{\gamma u^{\prime}\left(S m+D^{*}\right)+\left(1-\gamma_{s}\right) u^{\prime}\left(t_{a} m+D^{*}\right)} .
$$

Let the utility functions of men satisfy CRRA, so that $u_{m}(x)=\frac{x^{\alpha}}{\alpha}$, where $0<\alpha<1$. Using the fact that $u_{m}^{\prime}(x)=\frac{u_{m}(x)}{x}$, it is straightforward to show that

$$
\frac{d D^{*}}{d m}=\frac{u\left(\mu_{m} m\right)-\frac{S m}{S m+D^{*}} \gamma u\left(S m+D^{*}\right)-\frac{t_{a} m}{t_{a} m+D^{*}}\left(1-\gamma_{s}\right) u\left(t_{a} m+D^{*}\right)}{m\left[\frac{1}{S m+D^{*}} \gamma u\left(S m+D^{*}\right)+\frac{1}{t_{a} m+D^{*}}\left(1-\gamma_{s}\right) u\left(t_{a} m+D^{*}\right)\right]} .
$$

Given that $u_{m}\left(\mu_{m} m\right)=\gamma u\left(S m+D^{*}\right)+\left(1-\gamma_{s}\right) u\left(t_{a} m+D^{*}\right)$ and $0<\frac{S m}{S m+D^{*}}, \frac{t_{a} m}{t_{a} m+D^{*}}<1$, the numerator is positive, and thus $\frac{d D^{*}}{d m}>0$. Thus both mehr and dowry are increasing in $m$. Moreover, from (15), and the fact that the utility function is CRRA,

$$
\left.\frac{d D^{*}}{d m}\right|_{\alpha \rightarrow 1}=\mu_{m}-t_{a}-\gamma\left(S-t_{a}\right)<\mu_{m}-t_{a}=\frac{d M^{*}}{d m} .
$$

Thus whenever the agents are not too risk-averse, i.e. $\alpha$ is not too small, Propositions 5 and 6 go through.

Remark 9 Finally, we allow for heterogeneity in the income levels of men and women, using the simplest possible framework that captures some of the trade-offs. Assume that there are two men, with income levels $m_{1}$ and $m_{2}$, where $m_{1}>m_{2}>0$, and two women with income levels $w_{1}$ and $w_{2}$, where $w_{1}>w_{2}>0$. Let $M(i, j)$ (respectively $D(i, j)$ ) denote the level of mehr (respectively dowry) in a marriage between a man with income $m_{i}$ and a woman with income $w_{j}$.

An equilibrium consists of a marriage market assignment $:^{30}$ and marriage market contracts $(M(i, j), D(i, j)), i, j=1,2$, such that given these contracts, (a) all agents who are married obtain a higher utility relative to what they would obtain if they do not enter the marriage market, (b) men take divorce decisions optimally, and (c) there exists no man $m_{i}$ and woman $w_{j}$, such that $m_{i}$ and $w_{j}$ are not matched under the assignment, and moreover they strictly prefer to marry each other, rather than follow the assignment.

We then argue that there is a competitive equilibrium that involves positive assortative matching, and marriage market contracts such that:

$$
\begin{aligned}
M(i, i) & =M(i, j)=m_{i}\left(\mu_{m}-t_{a}\right), i, j=1,2, \\
D(i, i) & =D(i, j)=m_{i}\left[\mu_{m}-t_{a}-\gamma\left(F-t_{a}\right)\right], i, j=1,2 .
\end{aligned}
$$

\footnotetext{
${ }^{30} \mathrm{An}$ assignment either matches an agent to exactly one agent of the other sex, or says that the agent remains single. An example of such an assignment could be one where there is positive assortative matching, with $m_{1}$ (respectively $m_{2}$ ) getting married to $w_{1}$ (respectively $w_{2}$ ), i.e. a high (resp. low) income man getting married to a high (resp. low) income woman.
} 
First note that these levels of mehr ensure that in any marriage, men make their divorce decisions efficiently. The result then follows since given these contracts, a man with income $m_{i}$ always has a utility of $\mu_{m} m_{i}$ irrespective of who he marries, or if he remains single. Thus men would not benefit if they had a different wife, or if they did not enter the marriage market. Further, given that there is positive assortative matching, we can mimic our earlier arguments to establish that in this equilibrium women strictly prefer to get married rather than remain single. Finally, given positive assortative matching, from (18) and (19) it is clear that all our comparative statics predictions in Propositions 5 and 6 go through. Further, this equilibrium generates the prediction that both the mehr, as well as the dowry levels of high income couples will exceed that of low income couples (see (18) and (19) ${ }^{31}$

\section{Extensions and Discussions: Property Rights over Women's Income}

The baseline framework has been kept parsimonious in an effort to focus on the essential tradeoffs. We now extend the analysis to allow for the fact that in patriarchal societies men typically have property rights over the income generated by their wives ${ }^{32}$ Formally, following a marriage, a man obtains a fraction $\lambda$ of his wife's income, where $0<\lambda<1$, so that $\lambda$ denotes men's property rights over their wives' income (see Anderson and Bidner 2015). Thus the post-marriage effective income of a man is given by $X[m+\lambda w]$, while that of a woman is given by $X(1-\lambda) w$, where $X \in\left\{S, t_{f}, t_{a}\right\}$ depending on the nature of the marriage.

In order to focus on economies where dowry is positive, it is necessary that remaining single is attractive for men, formally

$$
m \mu_{m}>m\left[\gamma_{s} S+\left(1-\gamma_{s}\right) t_{a}\right]+\lambda w\left[\gamma_{s} S+\left(1-\gamma_{s}\right) t_{a}\right]
$$

The second term in the RHS of 20 refers to expected gains accruing to a man from his property rights over his wife's income. Thus 20 is the analogue of $(9)$ in the preceding section. Moreover, 20 also ensures that

$$
m \mu_{m}>m t_{a}+\lambda w t_{a}
$$

so that a man prefers to divorce his wife rather than continue in a marriage that is average, ensuring that mehr is also positive.

\footnotetext{
${ }^{31}$ We cannot rule out the possibility that there can be equilibria with negative assortative matching. This is because we do not allow for any complementarity between the income levels. We conjecture that if one allows for such complementarity, e.g. if the aggregate surplus in case of a marriage between $m_{i}$ and $w_{j}$ is given by $X\left(m_{i}+w_{j}+m_{i} w_{j}\right), X \in\left\{F, t_{f}, t_{a}\right\}$, then the unique equilibrium assignment would involve positive assortative matching.

${ }^{32}$ Men's rights on women's earning in patriarchal societies such as Bangladesh is well-recognized. Even in cases where women borrow from MFIs such as the Grameen Bank that exclusively focuses on women, men often decide loan's utilization, as well as take the profit (Rahman 2008).
} 
One can mimic the earlier analysis to show that whenever the marriage is either successful, or average, divorce is not efficient. Further, the aggregate ex ante surplus from marriage exceeds that from remaining single. Divorce never takes place in case the marriage is a successful one, since a man's payoff from a stable marriage exceeds that in case of a divorce, i.e. $S[m+\lambda w]+D>$ $\mu_{m} m+D-M$. Otherwise, in state $t_{i}$, divorce happens if and only if $t_{i}[m+\lambda w]+D<\mu_{m} m-M+D$, i.e. $M<m\left[\mu_{m}-t_{i}\right]-\lambda w t_{i}$.

Recalling that mehr is set at the minimum level that prevents inefficient divorce in case the marriage is average, one therefore has

$$
M^{*}=m\left[\mu_{m}-t_{a}\right]-\lambda w t_{a},
$$

so that given $M^{*}$, men are indifferent between divorcing their spouses, and continuing in average marriages. Note that mehr $M^{*}$ is positive given 21]. Moreover, it is lower compared to that in the baseline model because in this framework staying married is more attractive to men since they get a share of their spousal income.

We now solve for the equilibrium dowry, $D^{*}$. Arguing as before, the equilibrium level of dowry is such that men are indifferent between remaining single, and getting married. Consequently, $D^{*}$ must satisfy $\mu_{m} m=\gamma_{s} S[m+\lambda w]+\left(1-\gamma_{s}\right) t_{a}[m+\lambda w]+D^{*}$, so that

$$
D^{*}=m\left[\mu_{m}-\gamma_{s} S-\left(1-\gamma_{s}\right) t_{a}\right]-\lambda w\left[\gamma_{s} S+\left(1-\gamma_{s}\right) t_{a}\right] .
$$

Proposition 10 below summarizes the preceding discussions.

Proposition 10 There is a unique equilibrium $\left(D^{*}, M^{*}\right)$ where the mehr $M^{*}$ is set at the minimum level that prevents inefficient divorce, i.e. (20), and the dowry $D^{*}$ ensures that the marriage market clears, i.e. it satisfies (23).

We now examine the impact of various shocks - income, and legal - on both mehr, as well as dowry. From 22 and 23, it is straightforward to see that

$$
\begin{aligned}
d M^{*} & =\left[\mu_{m}-t_{a}\right] d m-t_{a} \lambda d w, \\
\text { and, } d D^{*} & =\left[\mu_{m}-\gamma_{s} S-\left(1-\gamma_{s}\right) t_{a}\right] d m-\lambda\left[\gamma_{s} S+\left(1-\gamma_{s}\right) t_{a}\right] d w .
\end{aligned}
$$

We next consider the absolute effect of an income shock on mehr. Note that while $M^{*}$ is positively related to $m$, it is negatively related to $w$. Thus the result is more nuanced and depends on the relative magnitude of any income shock on $m$ and $w$. Given that the labour market for women is an imputed one, it is however difficult to empirically establish whether the changes in $m$ were of a larger or smaller order of magnitude compared to that in $w$. We therefore focus on the benchmark case where any income shock generates identical proportional changes in $m$ and $w$, so that $d w / w=d m / m$. From 24

$$
\begin{aligned}
d M^{*} & =m\left(\mu_{m}-t_{a}\right) \frac{d m}{m}-w t_{a} \lambda \frac{d w}{w} \\
& =\left[m\left(\mu_{m}-t_{a}\right)-w t_{a} \lambda\right] \frac{d w}{w}=M^{*} \frac{d w}{w} .
\end{aligned}
$$


One can similarly argue that

$$
\begin{aligned}
d D^{*} & =m\left[\mu_{m}-\gamma_{s} S-\left(1-\gamma_{s}\right) t_{a}\right] \frac{d m}{m}-\lambda w\left[\gamma_{s} S+\left(1-\gamma_{s}\right) t_{a}\right] \frac{d w}{w} \\
& =\left[m\left[\mu_{m}-\gamma_{s} S-\left(1-\gamma_{s}\right) t_{a}\right]-\lambda w\left[\gamma_{s} S+\left(1-\gamma_{s}\right) t_{a}\right]\right] \frac{d w}{w}=D^{*} \frac{d w}{w} .
\end{aligned}
$$

Thus both mehr and dowry increase with a positive income shock, and decrease in case of a negative one whenever the proportionate changes in the income of men and women are not too dissimilar.

We next compare the effect of income shocks on mehr relative to that on dowry. To that end note that:

$$
\frac{d M^{*}-d D^{*}}{d m+\lambda d w}=\gamma_{s}\left(S-t_{a}\right)>0 .
$$

Consider a positive income shock, so that $d m, d w>0$. Then from (28), $0<d D^{*}<d M^{*}$. Whereas for a negative income shock (so that $d m, d w<0$ ), from 28 it follows that $-d M^{*}>$ $-d D^{*}>0$. Thus following any income shock, the absolute value of the change in mehr exceeds that in dowry. Moreover, income shocks generate the same rate of change in mehr and dowry; formally

$$
\frac{d \log M^{*}}{d m}=\frac{1}{m}=\frac{d \log D^{*}}{d m} .
$$

Proposition 11 Consider the effect of income shocks on mehr and dowry. Let the changes in the income of men and women be not too dissimilar, formally let the income shock lead to identical proportional changes, i.e. $d w / w=d m / m$. Following a positive (respectively negative) income shock the equilibrium mehr and dowry increase (respectively decrease) at the same rate.

We then consider the effects of the MFLO of 1961 and the MMDA of 1974. Mimicking the preceding analysis we can show Proposition 7 goes through, so that the MMDA and the MFLO have qualitatively similar impacts in this case.

Finally, we should point out that while the GR was staggered over the 1960s, the IW and famine happened over a three year period in the 1970s. Given this longer temporal spread, and the fact that women benefited during the GR, we expect that the GR will lead to an increase in the property rights of women in the long run, i.e. cause a fall in $\lambda$. Given 22) and (23), a fall in $\lambda$ can be expected to increase both mehr and dowry in the long run. These long term effects may counteract some of the negative income shocks during the IW and famine episodes.

Finally, we briefly discuss some of the other modelling decisions made in this paper:

1. Motivated by the institutional realities in Bangladesh as well as in India and Pakistan, we assume that mehr is a conditional payment made only in the event of a divorce. Mehr is usually divided into two parts, a prompt mehr which is payable immediately on marriage, and a deferred mehr which is paid in case of divorce (Rapoport 2000, Welchman 2000). In Bangladesh while the formal marriage contract (kabin) can involve both forms of mehr, 
typically most of the mehr is deferred, rather than prompt (Kamal 2001, Huda 2006). This was also verified by Ambrus et al. (2010), who found that in their data none of the marriages had a prompt mehr exceeding $\$ 1$.

2. While we follow the literature in assuming that dowry acts as a groom price that clears the marriage market, it may be of interest to examine as to what happens if dowry also involves some negotiations between the two concerned families. It may be argued that allowing for such inter-family bargaining may capture some elements of reality in these societies. Consider an alternative framework where mehr is still set so as to prevent inefficient divorce, but dowry is settled through asymmetric Nash bargaining between the families. We find that that there is a close connection between the dowry levels in this formulation and our baseline model. Moreover, under some additional conditions the comparative statics results are qualitatively similar under both formulations, and would thus yield very similar testable hypotheses ${ }^{33}$

3. There is some evidence to suggest that, in Bangladesh, till the early 1970s pre-mortem bequest to daughters, i.e joutuk, was a component of dowry. Arunachalam and Logan (2006) argue that, relative to groom-price dowries, bequest dowries have decreased in prevalence and amount over time ${ }^{34}$ This is the position taken, among others, by Anderson and Bidner (2015). For completeness, we briefly discuss this possibility. The theoretical prediction from this literature (Zhang and Chan 1999, Edlund 2000, Botticini and Siow 2003, Brown 2009) is that the dowry does not depend on the productivity of the groom and is decreasing in the income of the bride. Thus in a framework where mehr still serves to prevent inefficient divorce, whereas dowry is a pre-mortem bequest, a positive income shock will have a positive effect on mehr, but no effect on dowry.

\section{$5 \quad$ Data and Descriptive Statistics}

To test our model predictions, we have utilized three household survey data sets; two of these were conducted in Bangladesh, and the third one in the Indian state of West Bengal that borders Bangladesh. All three surveys used identical modules on marriage, divorce, mehr and dowry. The first survey was administered to 1,820 households in 91 villages across all major geographical regions of Bangladesh in between December 2010 and January 2011 35 After employing the cleaning steps described below, the sample contains 1,981 marriages in 1,457 households.

\footnotetext{
${ }^{33}$ The details are in Appendix 1.

${ }^{34}$ The data sets used for the empirical analysis do not allow us to separate out bequest dowry from total dowry. Although information about three types of dowry, both cash and kind such as jewelry, land and animals, and their ownership was collected, monetary value of only total dowry was ascertained. Since marriages involve multiple types of dowries and their complex ownerships, the value of bequest dowry cannot be separated.

${ }^{35}$ These households were drawn from an earlier existing survey commissioned by Palli Karma Shahayak Foundation (PKSF) and conducted by the Bangladesh Institute of Development Studies (BIDS) in 1997-98.
} 
The second data set was collected between December 2004 and January 2005 for the Bangladesh Rural Urban Linkage Survey (BRULS) by the International Food Policy Research Institute (IFPRI). It was a follow-up study to the Household Income and Expenditure Survey (HIES) of 2000 conducted by the Bangladesh Bureau of Statistics (BBS). In HIES 2000, the BBS surveyed 1,360 rural households drawn from 68 villages (mouzas) in 16 districts of the Rajshahi Division. In 2004, BRULS re-surveyed 1,271 households from the existing sample (6.5 percent attrition) and also added 200 new households from 10 new villages in the same division, so that the sample had 1471 households drawn from 78 villages. After employing the same cleaning steps described below, the sample has 1,367 marriages in 865 households.

The third data set was collected from 2,000 households drawn from 100 villages distributed over six districts in West Bengal. All these districts (Cooch Behar, Malda, Murshidabad, Nadia, North Dinajpur, and South Dinajpur) are adjacent to Bangladesh (Appendix 2, Figures A2 \& A3), and all of them with the exception of one share borders with Bangladesh. The survey was commissioned by the Indian Statistical Institute (ISI), Delhi and was conducted by the National Field Service of India (NFSI) in between December 2014 and January 2015.

To create our working sample we adopt the following cleaning procedure. First, only Muslims households are included (by discarding all non-Muslim households); second, only households members between 18 and 65 years of age are included; third, only first marriages are included; fourth, only relationships involving household heads, spouses or sons/daughters are included; and finally, missing values of dowry and mehr are deleted. In both the datasets from Bangladesh, real values of dowry and mehr have been calculated using the price deflater reported in the online Appendix in Ambrus et al. (2010). For the West Bengal data, the consumer price indices published by the Ministry of Statistics and Program Implementation, India, has been used to calculate the real values of dowry and mehr.

Figure 1 shows the trends in logarithmic values of dowry and mehr observed in the PKSF data, where we plot the real mean values by year for these variables. For ease of exposition, the three natural shocks discussed in Section 2 , the Green Revolution (GR), the war of independence (IW), and famine of 1974 (Fam), are marked along the horizontal axis. It is evident that both dowry and mehr fluctuated considerably from the 1950s through the 1970s and then both stabilized in the subsequent period. We attribute these large fluctuations in earlier periods to the small number of observations because of the survivorship bias ${ }^{36}$ However, some patterns can

\footnotetext{
${ }^{36}$ In our case, survivorship bias refers to the fact that only a small fraction of individuals who married in earlier periods were alive during the survey. In the BRULS survey, the percentages of observations in the pre-GR, GR, IW-famine and post-famine periods are $0.59 \%, 3.29 \%, 2.64 \%$, and $93.49 \%$, respectively. In contrast, the respective numbers in the PKSF data are 4.04\%, 9.19\%, 5\%, and $81.78 \%$. One explanation is that the rural northwestern region in Bangladesh, where BRULS was conducted, has historically been the poorest region in the country, with the highest incidence of poverty and the shortest life expectancy.39 Therefore, the number of surviving married individuals who married in earlier periods is smaller in the BRULS dataset. In contrast, the PKSF data covers all of Bangladesh, thereby reducing survivorship bias in the sample. In the West Bengal data, the percentages of observations in the pre-GR, GR and post-GR periods are $1.5 \%, 6.7 \%$, and $91.8 \%$, respectively.
} 
be observed from the graph. Both dowry and mehr were larger in the pre-war period compared to the post-famine period. Further, although both increased secularly since the mid-1980s with the increase in mehr being more pronounced, they did not revert to their pre-famine levels.

\section{[Insert Figure 1 and Table 1 about here]}

Table 1 presents the descriptive statistics for the real values of dowry and mehr, which help clarify the trends observed in Figure 1, and several bride-groom characteristics controlled in the analysis. The logarithm of real value of mehr (in Taka) substantially increased from an average of 8.334 in the pre-GR period, to 8.98 in the GR period (in absolute value, this is increase from 18,009 taka to 56,759 taka). Then it declined to 8.79 in the IW-famine period. In the absence of any further shock, it increased to 9.17 over the long horizon of the post-1974 (1975-2010) period. A similar trend is observed in case of dowry as well. The BRULS and West Bengal data also depict similar trends (Appendix 2, Figures A4 and A5, and Tables A1 and A2) 37 In terms of bride and groom attributes, the average year of schooling of the brides increased over time. In the PKSF data, for example, it increased to 3.98 in the post-famine period from 0.78 in the pre-GR period. The age at marriage also increased for the brides over the same time period (from 13.5 to 16.5 ), while that for grooms remained almost unchanged.

\section{Estimation Strategy}

To test the impact of the natural shocks on the values of dowry and mehr, we estimate the following two equations:

$$
\begin{gathered}
\ln M_{i y}=\alpha^{M}+\gamma^{r}+\beta^{M} \mu_{y}+\delta^{M} X_{i y}^{M}+\varepsilon_{i y}^{M} \\
\ln D_{i y}=\alpha^{D}+\gamma^{r}+\beta^{D} \mu_{y}+\delta^{D} X_{i y}^{D}+\varepsilon_{i y}^{D}
\end{gathered}
$$

where $\ln M_{i y}$ and $\ln D_{i y r}$ are the logarithm of the real value of mehr and dowry ${ }^{38}$ respectively, for a woman $i$ married in year $y$, and $\mu_{y}$ is a vector of three dummy variables for four time periods and are the same in both equations: (i) pre-GR, (ii) GR (1961-1970), (iii) IW-famine (1971-1974), and (iv) post-famine (post-1974). $\gamma^{r}$ is the set of regional (district) dummies to account for geographic variations in dowry and mehr. Given the exogeneity of the shocks, our

\footnotetext{
${ }^{37}$ It is important to mention that values of dowry and mehr among Muslims are substantially lower in West Bengal than in Bangladesh after adjusting for the exchange rate. This difference, although an interesting topic on its own right, is beyond the scope of the current investigation.

${ }^{38}$ As the steps outlined to select the working sample retain only positive values of dowry and mehr (there was no zero values), logarithmic transformation does not decrease the sample size in our analysis. Given large fluctuations in dowry and mehr, such transformation is also very useful in accounting for heteroskedasticity.
} 
identification relies entirely on the pre-post comparisons. To find out the effect of a particular shock, we compare the values of both mehr and dowry after the shock with the respective values in the previous period: the GR values with the pre-GR values; the IW-famine values with the GR values, and the post-famine values with the IW-famine values. ${ }^{39}$

Both the vectors $X^{M}$ and $X^{D}$ include an indicator of relationship to the household head (specifically, whether the woman is the daughter-in-law as opposed to the daughter or wife of the household head), a polynomial of the marriage year up to order three (to capture the nonlinearity in the trend of the values of mehr and dowry). They also include a set of attributes of brides and grooms: age and education differences between the bride and the groom, two dummies for relative wealth of the brides' and grooms' families 40 at the time of marriage, and an indicator of whether the groom chose the bride or the marriage was arranged by the families. When mehr is the dependent variable, the equation includes the brides' education and age in the regression. Similarly, in case of dowry, the estimating equation includes the grooms' education and age in the regression 41

In the marriage market literature since Becker (1973), it is widely recognized that brides and grooms have preferences for certain attributes and that such preferences can lead to the emergence of marriage-related payments. Moreover, the nature and direction of such payments are often affected by socio-economic factors (Anderson 2003). Empirical evidence pertaining to both developed (Hitsch et al. 2010) and developing countries (Rao 1993, Edlund 2000) usually supports the existence of preferences regarding spousal attributes. One might argue that bride and groom attributes are endogenous. However, our main focus is on the $\beta^{M}$ and $\beta^{D}$ coefficients, which compare average values of mehr and dowry, respectively, in different periods. Given that the relevant economic and political events are completely exogenous, the estimated $\beta^{M}$ and $\beta^{D}$ coefficients will be unbiased even without controlling for bride and groom attributes. In all estimations, the standard errors are clustered at the household level.

We apply our main empirical estimation strategy to PKSF and BRULS data, as well as to a combined data set constructed by merging these two data sets. Merging the two datasets is justified as the information used in the analysis is the year of marriage and the values of mehr and dowry paid or specified as part of the marriage, which are independent of the timing of the survey. The same is true of bride and groom attributes at the time of marriage.

\footnotetext{
${ }^{39}$ Equations 30 and 31 are estimated independently. However SURE estimations give qualitatively similar results. See Ambrus et al. (2010) who also estimated the mehr and dowry equations independently.

${ }^{40}$ Relative wealth is categorized into three groups, depending on whether the brides' family was (i) economically richer, (ii) poorer, and (iii) equal relative to the groom's family.

${ }^{41}$ Other attributes such as skin tone and height (Banerjee et al. 2013) are not controlled for in the regression as such data were not collected; the caste system is absent among Muslims.
} 


\section{$7 \quad$ Empirical Results}

Before presenting the results, it is worth reiterating the predictions of the model developed in Section 3.1.1. Recall that the GR increases, while IW-famine decreases, the value of mehr and dowry similarly. We compare the values of mehr and dowry in the GR period relative to pre-GR period, and the same in the post-IW-famine (post-1974) relative to the GR period.

In the following, we first present the results for the two data sets in Bangladesh and then check robustness using the data from the West Bengal. The latter results are also used to counter the alternative explanation of the fluctuations in dowry and mehr values such as legal changes in Bangladesh.

\subsection{Results from the PKSF (2010) data}

The regression results for this dataset are presented in Table 2. The (log) values of mehr and dowry are estimated relative to the pre-GR period, which is the base category in the regression. The values in the subsequent periods relative to their previous period are reported at the bottom of the table. Column 1 presents the results for mehr, without controlling the attributes of brides and grooms. The value of mehr increased significantly during the GR relative to the previous period (the coefficient is 0.672 with a t-value of 1.987 ). Further, although the value of mehr did not decline in the IW-famine period (1971-74) compared to the GR level, it declined significantly in the post-famine period (the coefficient is -1.163 with a t-value of -3.631). Lastly, it declined in the post-famine period vis-á-vis the IW-famine period (the coefficient is -0.899 with a t-value of -3.336). These results are robust to controlling for bride and groom attributes (column 3). The value of dowry did not change in the GR period from its pre-GR level (the sign is positive as expected although not statistically significant), but otherwise it followed a trend similar to that of mehr (columns 2 and 4).

We test the equality of the coefficients of log mehr and dowry and report the chi-square statistics for the null hypothesis that they are equal. Comparison of the results (columns 1 vs. 2; columns 3 vs. 4) indicate that the null is not rejected in all cases; in any given period the change in values of mehr and dowry are not statistically different. In the imperative to mention that we obtain this equality for the GR period as well although the magnitudes of two coefficients differ by a wide margin. The reason is that number of observations in this period (number of reported marriage in earlier period) is low due to the survivorship bias. ${ }^{42}$ These results strongly support our model's predictions.

\section{[Insert Table 2 about here]}

\footnotetext{
${ }^{42}$ One might question if our results are driven by employment of women in the garment sectors in 1990s and female secondary school stipend programs in 1994. The results remain unchanged if the sample period is restricted to 1989; the post famine period then becomes 1975-1989 (See Appendix 2, Table A3).
} 


\subsection{Results from the BRULS (2004) data}

The regression results for this one are presented in Table 3. Column 1 presents the results for mehr when bride and groom attributes are excluded from the regression. The value of mehr increased during the GR compared to the pre-GR period, but the difference is not statistically significant. It decreased in the post-famine period relative to the GR period, but the difference is again not statistically significant. However, the value of mehr decreased significantly in the post-famine period relative to the IW-famine period (the coefficient is -0.634 with a t-value of -1.806), a result that is qualitatively similar when the bride and groom attributes are included (column 3). The value of dowry followed a very similar trend. Comparing the results with PKSF data, the main difference is that the change in mehr in the GR period is insignificant. However, in contrast to the value of mehr, the value of dowry significantly decreased in the post-famine period from its GR level; the coefficient ( $\mathrm{t}$-value) is $-0.730(-1.864)$ when bride and groom attributes are excluded and $-0.834(-2.218)$ when these attributes are included (columns 2 and 4$)$.

Comparison of the results for mehr and dowry again indicate that in any given period the change in values of mehr and dowry are not statistically different, thus providing qualified support for the model's predictions.

The insignificance of the results in the BRULS data relative to the PKSF data may be due to a smaller sample size and larger survivorship bias. To address these, our final exercise in the next section involves merging the PKSF and BRULS datasets.

[Insert Table 3 about here]

\subsection{Results from the merged (PKSF and BRULS) data}

The regression results are presented in Table 4. The results for mehr, without and with inclusion of the bride and groom attributes, are presented in columns 1 and 3, respectively. The corresponding results for dowry are presented in columns 2 and 4, respectively. All of these results are similar to those obtained using the PKSF data and with higher levels of statistical significance.

To summarize, the results indicate that the value of mehr increased during the GR period and then declined during both the IW-famine and post-famine periods. However, only the decline in the latter period is statistically significant, probably owing to the time lag required for the effect of the shock to be realized. The increase in dowry during the GR period is not significant (although the sign is as expected) but otherwise followed a trend similar to that of mehr with a change of smaller magnitude. Finally, in any given period the change in values of mehr and dowry are not statistically different. 
These results are consistent with the theoretical predictions summarized in Section 3.1.1. More specifically, the GR had a positive effect, and the IW-famine had a negative effect, on both mehr and dowry and the rate of changes are not different.

[Insert Table 4 about here]

\section{Other Plausible Explanations}

We next examine other possible explanations for the observed patterns in mehr and dowry, in particular legal changes and missing women. We argue that these factors do not explain the observed patterns in mehr and dowry.

\subsection{Natural shocks or legal changes?}

As discussed in Section 3, in the post-1960 period, there were two legal changes in Bangladesh aimed at restricting polygamy among Muslims and curb the practice of dowry that coincided with the natural shocks - the MFLO in 1961 and the MMDA in 1974. Our theoretical predictions contradict Ambrus et al. (2010) who theorize that the MFLO increases both dowry and mehr (see Section 3.1.2). In contrast, both our framework as well as Ambrus et al. (2010) suggest that the MMDA decreases both dowry and mehr. Given that both income shocks and legal changes occurred at the same time, empirically disentangling the effect of natural shocks from the legal changes is a daunting challenge. In the following, we do that by exploiting another natural experiment from the Indian state of West Bengal. In Appendix 3, we also demonstrate that the empirical results reported in Ambrus et al. (2010) are sensitive to their empirical methodology.

\subsubsection{Evidence from the Indian state of West Bengal: Another natural experiment}

In 1947 (United) Bengal was partitioned by the British into two regions, while the eastern region became a part of Pakistan (East Pakistan, now Bangladesh), the western region became a part of India (West Bengal). Bangladesh and West Bengal are not only similar in many respects including climate, geography, language, and level of economic development, but also the new agricultural technologies under the GR were introduced in Bangladesh and West Bengal almost at the same time. However, being parts of two different countries, Bangladesh and West Bengal differ in terms of legal changes introduced after 1947. Therefore if the changes in the values of mehr and dowry in West Bengal mirror those in Bangladesh during the GR period, we can conclude that these changes are driven by the GR and not by legal changes.

In examining West Bengal we follow an approach similar to Banerjee et al. (2002) that takes the agriculture sector of Bangladesh as a valid counter-factual for that in West Bengal and identifies the effect of a policy change (tenancy reform) in West Bengal on agricultural rice 
yields by comparing rice yields in Bangladesh (through a difference-in-difference method). They relied on the assumption that in the absence of the policy reform, agriculture was growing at the same rate in both countries. Similar to Banerjee et al. (2002) we test if agricultural growth was the same in the Bangladesh and the West Bengal districts between 1961 and 1970. We regressed agricultural value added over the period 1961-70 against year dummies and an indicator that tracks if the district is in Bangladesh or not ${ }^{43}$ Similar to Banerjee et al. (2002), the hypothesis is rejected as the coefficient on the Bangladesh dummy is not significantly different from zero 44

In the absence of negative shocks in West Bengal, such as the IW or famine, we expect no decline in dowry and mehr after 1974. Although about 1.5 million refugees from Bangladesh took shelter in bordering Indian regions including West Bengal, and some West Bengal districts may have suffered from the flood of 1974 (that was one of the reasons for the famine in Bangladesh), there were no reports of either famine or extreme hunger in these districts of West Bengal. Therefore, there is no evidence to argue that during the 1971-74 period there was any negative shock in West Bengal.

We choose the following cut-off periods: (i) pre-GR (pre-1961), (ii) GR (1961-1974), and (iii) post-1974. The 1974 cut-off is chosen so as to compare the effect of the legal changes that occurred in Bangladesh. We expect, based on our theoretical framework, that mehr would have increased in the 1961-1974 period relative to the pre-GR period. In the absence of any further shocks, the values of dowry and mehr would have stabilized and therefore no significant changes are expected in the post-1974 period.

\section{[Insert Table 5 about here]}

The results are presented in Table 5. Columns (1) and (2) present the results for mehr without and with controlling for the attributes of the brides and grooms, respectively. In both specifications, the value of mehr increased significantly in the 1961-1974 period, but there were no significant change in post-1974 period relative to the 1961-1974 period. There were no significant changes in the value of dowry in either 1961-1974 or post-1974 period. In the GR period, the rates of change for both mehr and dowry are not different. The results strongly support our argument that natural shocks but not legal changes explain the changes in the values of mehr and dowry. Choosing 1961-1970 as the GR period similar to Bangladesh does not make any difference in our empirical results (see Appendix 2, Table A4).

\footnotetext{
${ }^{43}$ For Bangladesh, the growth data is calculated from agricultural value added in constant LCU. The data source is the online World Development Indicators of the World Bank. For West Bengal the growth is calculated from agricultural yield data for six separate districts (Cooch Behar, Malda, Murshidabad, Nadia, North Dinajpur, and South Dinajpur) from where we collected our marriage market data. The data is sourced from various issues of Statistical Abstract of the West Bengal Government.

${ }^{44}$ The coefficient of the Bangladesh dummy is -3.73 with a t-stat of -0.59 .
} 


\subsection{Missing Women and Marriage Squeeze}

We then examine if the increased mehr in the 1960s was a result of missing women (a term coined in Sen 1990). The gender ratio (the number of males per 100 females) at birth in Bangladesh remains normal in the sense that it is similar to countries where prenatal discrimination is not observed or reported (UNFPA 2012).

Bangladesh however had high excess female mortality rate (Kabeer et al., 2013). In addition, age-specific sex ratio and marriage rates need to be considered while examining if missing women and marriage squeeze were happening in Bangladesh. In Appendix 2, Table A5 shows gender ratios at different age group for the period 1951-2011 collected for various census years. It is clear that the gender ratio at birth in Bangladesh had not changed in the 1950s and 1960s. Besides, missing women and abnormal rise in the proportion of male births in India (West Bengal) and other developing countries, is mostly a post-1970s phenomenon owing to the availability of prenatal sex determination technologies (Sen 1990, UNFPA 2012).

However, there was an abrupt decline in the number of males between 20 and 29 years, implying that at marriage age, the number of girls exceeds the number of boys 45 It should be noted that this trend was observed since the 1950s and did not experience any significant change in the 1960s and 1970s. Hence this phenomenon is unlikely to be confounded with either of these natural shocks.

\section{Conclusion}

In this paper we seek to explain the evolution of mehr and dowry in Bangladesh since the 1960s in terms of natural shocks. We first develop a model based on the institutional realities in our setting in which the role of dowry is to ensure that the marriage market clears and the role of mehr is to ensure the efficiency of the marriage market. Our comparative statics results show that the observed fluctuations in mehr and dowry can indeed be explained as responses to exogenous income shocks.

To test the model predictions, we exploit several natural experiments. In Bangladesh, the introduction of modern agricultural technologies in the 1960s, popularly referred to as the Green Revolution, caused a substantial increase in agricultural productivity. Subsequently, the country was subject to several negative shocks, first the devastating Independence War of 1971, followed in 1974 by a famine that primarily affected the rural households. Our empirical results find support for the model predictions in that the value of mehr increased significantly during the GR period (1961-1970). Further both mehr and dowry decreased in the post-famine period. In all cases, directions and rate of changes of mehr and dowry are the same. Taken together these results suggest that natural shocks affect how social institutions evolve over time, an insight

\footnotetext{
${ }^{45}$ One plausible explanation of this phenomenon is high incidence of age-specific, both internal and international, migration of males from Bangladesh.
} 
that may well be true beyond the specific example studied in this paper.

To check the robustness of our results, we exploit another natural experiment from the Indian state of West Bengal (bordering Bangladesh) that also experienced an increase in agricultural productivity around the same period. The results from these data strongly corroborate the results obtained in the context of Bangladesh. Equally importantly, given that West Bengal experienced a similar GR but was not subject to any of the legal changes that occurred in Bangladesh (being a part of India), these results suggest that the effects on mehr and dowry can be traced to income, rather than legal shocks.

It is important to note that agricultural productivity gradually increased in Bangladesh in the post-1980 period. This increase may be attributed to cumulative experiences gained over time since the GR shock, increasing role played by NGOs in the agricultural sector or innovation of newer rice varieties but none of them can be regarded as an exogenous shock. Another important aspect of the development process in Bangladesh is that the aggregate growth in the 1960s was driven mainly by the growth in agricultural sector, while the same in the post-1980 period was driven by the growth in non-agricultural sector in urban areas. We also observe in the data that there have been no sharp changes in the values of dowry and mehr or even persistent gradual changes to indicate trend reversion since the last shock during the famine, which suggests that the impacts of last negative shock still persist.

Acknowledgments: We would like to thank Arnab Basu, Christopher Barrett, Robert Barro, Shahe Emran, Abhiroop Mukhopadhyay, Fahad Khalil, Tridip Ray, conference participants at the IZA, the 10th Australian Development Economics Workshop, 2015 ASSA meeting, the 11th ACEGD, the ISI Growth and Development Conference, 2015, audiences at Gottingen University, Erasmus University, Indian Statistical Institute, and Jadavpur University for their helpful comments. We thank Dyotona Dasgupta and Shilpi Mukherjee for their help in the process of data collection. All errors and omissions are the sole responsibility of the authors. 


\section{References}

Ambrus, A., E. Field, and M. Torero. 2010. Muslim Family law, Prenuptial Agreements and the Emergence of Dowry in Bangladesh, Quarterly Journal of Economics 125(3): 1349-1397.

Amin, S., and M. Cain. 1997. The Rise of Dowry in Bangladesh, in The Continuing Demographic Transition, Gavin W. Jones, Robert M. Douglas, John C. Caldwell, and Rennie M. D'Souza, eds. Oxford, UK: Clarendon Press.

Anderson, S. 2003. Why Dowry Payments Declined with Modernization in Europe but are Rising in India. Journal of Political Economy, 111(2): 269-310.

Anderson, S. 2007. The Economics of Dowry and Bride-price. Journal of Economic Perspectives 21(4):151-174.

Anderson, S., and C. Bidner. 2015. Property Rights over Marital Transfers. Quarterly Journal of Economics, 130(3): 1421-1484.

Arunachalam, R., and T. D. Logan. 2006. On the Heterogeneity of Dowry Motives. National Bureau of Economic Research Working Paper 12630.

Banerjee, A., E. Duflo, M. Ghatak, and J. Lafortune. 2013. Marry for What? Caste and Mate Selection in Modern India. American Economic Journal: Microeconomics, 5(2): 33-72.

Banerjee, A., P. Gertler, and M. Ghatak. 2002. Empowerment and Efficiency: Tenancy Reform in West Bengal. Journal of Political Economy, 110(2): 239-280.

Baxter, M. and R. G. King. 1999. Measuring Business Cycles: Approximate Band-Pass Filters For Economic Time Series. Review of Economics and Statistics, 81(4): 575-593.

BBS (Bangladesh Bureau of Statistics) 2005. Household Income and Expenditure Survey Report. Dhaka.

Becker, G.S. 1973. A Theory of Marriage: Part I. Journal of Political Economy, 81(4): 813-846.

Becker, G.S. 1981. A Treatise on the Family. Harvard University Press, Cambridge, Massachusetts, London, England.

Bianquis, T. 1996. The Family in Arab Islam. In: A History of the Family. Vol 1 of Distant Worlds, Ancient Worlds. Ed. A. Burguiere, C. Klapisch-Zuber, M. Segalen, and F. Zonabend, 601-47. Cambridge: Polity Press.

Borker. G., J. Eeckhout, N. Luke, S, Minz, K. Munshi and S. Swaminathan. 2017. Wealth, Marriage and Sex Selection, mimeo.

Botticini, M., and A. Siow, 2003. Why Dowries?, American Economic Review, 93(4): 13851398.

Brandt, M., and J. Kaplan. 1995-1996. The Tension between Women's Rights and Religious Rights: Reservations to Cedaw by Egypt, Bangladesh and Tunisia. Journal of Law and Religion, 12(1): 105-142.

Brown, P.H. 2009. Dowry and Intrahousehold Bargaining: Evidence from China, Journal of 
Human Resources, 44(1): 25-46.

Browning, M., Chiappori, P.A. and Y. Weiss, 2014. Economics of the Family. Cambridge University Press.

Carroll, L. 1986a. Talaq Pronounced in England and Perfected by Post Not Recognised: Fatima in the House of Lords. Modern Law Review, 49(6): 776-781.

Carroll, L. 1986b. A Note on the Muslim Wife's Right to Divorce in Pakistan and Bangladesh. Journal of Ethnic and Migration Studies, 13(1): 94-98.

Cherchye, L., Rock, B. D., Vermeulen, F., and S. Walther, 2016. Where did it go Wrong? Marriage and Divorce in Malawi, mimeo, University of Leuven.

Cherchye, L., Demuynck, T., Rock, B. D., and F. Vermeulen, 2017. Household Consumption when the Marriage is Stable, American Economic Review 107 (6), 1507-1534.

Cole, H. L., G. J. Mailath, and A. Postlewaite. 2001. Efficient Non-Contractible Investments in Large Economies, Journal of Economic Theory, 101 (2): 333-373.

D'Agostino, A.L. 2017. Technical Change and Gender Wage Inequality: Long-Run Effects of India's Green Revolution. Columbia University.

David, C., and K. Otsuka (Eds). 1994. Modern Rice Technology and Income Distribution in Asia. Boulder, Col.: Lynne Rienner.

Dreze, J. and A. Sen. 1995. India: Economic Development and Social Opportunity. Clarendon Press.

Edlund, L. 2000. The Marriage Squeeze Interpretation of Dowry Inflation: A Comment. Journal of Political Economy, 108 (6): 1327-1333.

Esteve-Volart, B. 2004. Dowry in Rural Bangladesh: Participation as Insurance Against Divorce. Manuscript. London School of Economics.

Falcon, W.P. and C.H. Gotsch. 1970. Lessons in Agricultural Development - Pakistan. In G.F. Papanek (Eds.). Development Policy: Theory and Practice. Cambridge, MA: Harvard University Press. Pp. 269-315.

Hitsch, G.J., A. Hortacsu, and D. Ariely. 2010. What Makes You Click? Mate Preferences in Online Dating. Manuscript. University of Chicago.

Hossain, M., A. Quasem, M. A. Jabbar, M.M. Akash. 1994. Production Environments, Modem Variety Adoption, and Income Distribution in Bangladesh. in David, C., and K. Otsuka (Eds). 1994. Modern Rice Technology and Income Distribution in Asia. Boulder, Col.: Lynne Rienner. 221-280.

Huda, S. 2006. Dowry in Bangladesh: Compromising Women's Rights. South Asia Research, 26(3): 249-268.

Kabeer, N., L. Huq, Mahmud S. 2013. Diverging Stories of missing womenİ in South Asia: Is son preference weakening in Bangladesh? Feminist Economics, 20(4): 138-163.

Kamal, S. 2001. Her Unfearing Mind: Women and Muslim Laws in Bangladesh. Ain O Salish Kendro, Dhaka, Bangladesh. 
Khan, A.R. 1972. The Economy of Bangladesh. Macmillan, London.

Peters, M., and A. Siow. 2002. Competing Premarital Investments, Journal of Political Economy, 110(3): 592-608.

Rahman, A. 2008. Women and Microcredit in Rural Bangladesh: An Anthropological Study of Grameen Bank Lending. Westview Press.

Rao, V. 1993. The Rising Price of Husbands: A Hedonic Analysis of Dowry Increases in Rural India. Journal of Political Economy, 101 (4): 666-77.

Rapoport, Y. 2000. Matrimonial Gifts in Early Islamic Egypt. Islamic Law and Society, 7(1): 1-36.

Riedel, B.O. 2011. Deadly Embrace: Pakistan, America, and the Future of the Global Jihad. Brookings Institution.

Rosen, S. 1974. Hedonic Prices and Implicit Markets: Product Differentiation in Pure Competition, Journal of Political Economy, 82(1): 34-55.

Sekhri, S., and A. Storeygard. 2014. Dowry Deaths: Response to Weather Variability in India, Journal of Development Economics, 111(C): 212-223.

Sen, A. 1990. More than 100 million women are missing. New York Review of Books, 37(20): 61-66.

UNFPA. 2012. Sex Imbalances at Birth: Current Trends, Consequences and Policy Implications. https://www unfpa.org/sites/default/files/pub-pdf/Sex\%20Imbalances\%20at\% 20Birth. \%20PDF $\% 20$ UNFPA\%20APRO\%20publication\%202012.pdf.

Vatuk, S. 2008. Islamic Feminism in India: Indian Muslim Women Activists and the Reform of Muslim Personal Law. Modern Asian Studies, 42(2-3): 489-518.

Welchman, L. 2000. Beyond the Code: Muslim Family Law and the Shari'a Judiciary in the Palestinian West Bank. Kluwer Law International, The Hague.

Zhang, J., and W. Chan. 1999. Dowry and Wife's Welfare: A Theoretical and Empirical Analysis, Journal of Political Economy, 107(4): 786-808. 
Figures \& Tables 


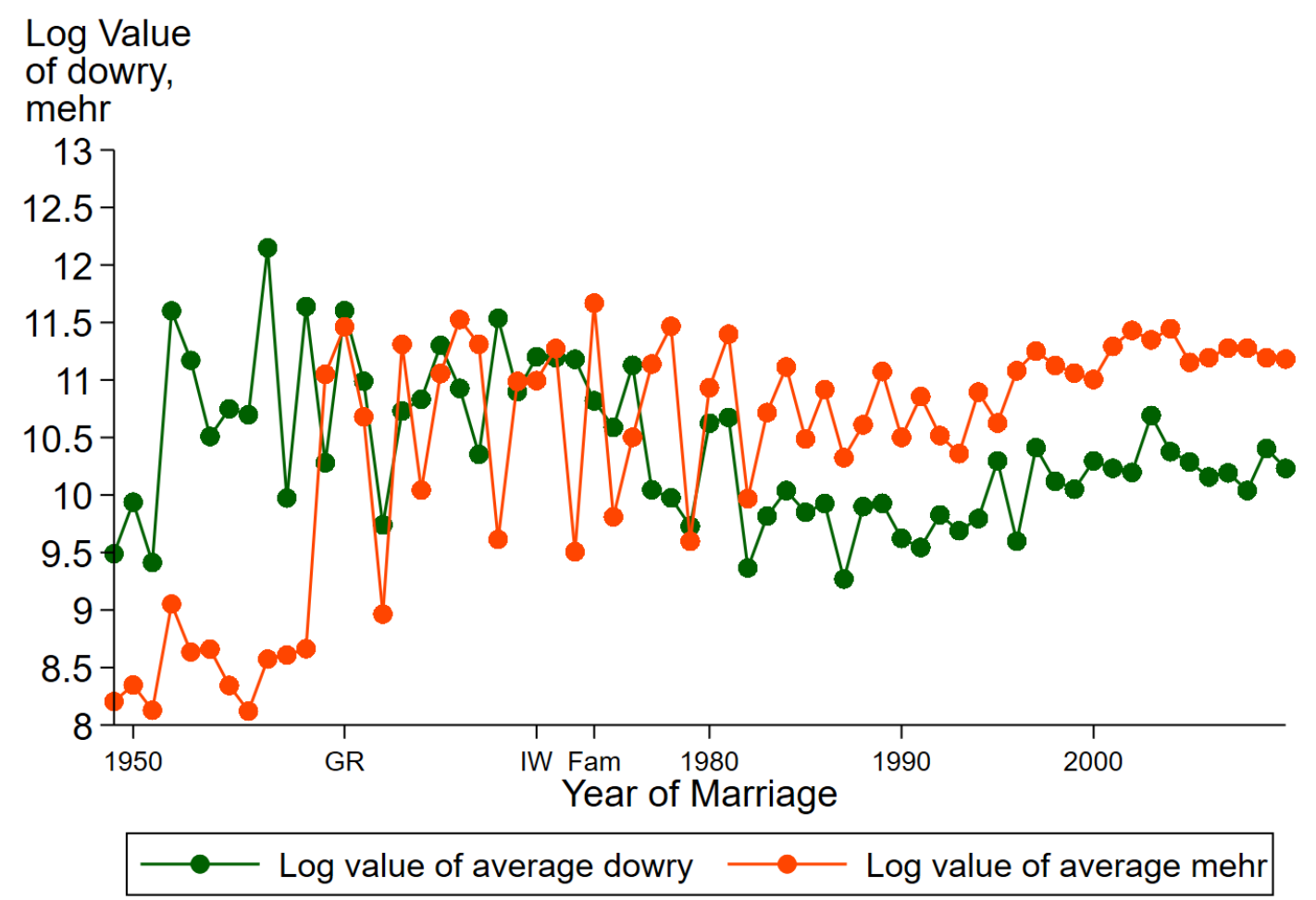

Figure 1: Mean Real Value of Mehr and Dowry by Year of Marriage (based on PKSF data) 
Table 1: Summary Statistics - PKSF (2010) data

\begin{tabular}{|c|c|c|c|c|c|}
\hline & $\begin{array}{l}\text { All } \\
\text { Marriages } \\
\text { over } \\
\text { the period } \\
\quad(1)\end{array}$ & $\begin{array}{c}\text { Regime I } \\
\text { Marriages } \\
\text { (before } \\
1961) \\
(2)\end{array}$ & $\begin{array}{c}\text { Regime II } \\
\text { Marriages } \\
(1961- \\
1970) \\
(3)\end{array}$ & $\begin{array}{c}\text { Regime III } \\
\text { Marriages } \\
(1971- \\
1974) \\
(4)\end{array}$ & $\begin{array}{c}\text { Regime IV } \\
\text { Marriages } \\
(1975- \\
2010) \\
(5)\end{array}$ \\
\hline Log value of mehr & $\begin{array}{c}9.102 \\
(0.055)\end{array}$ & $\begin{array}{c}8.334 \\
(0.105)\end{array}$ & $\begin{array}{c}8.984 \\
(0.128)\end{array}$ & $\begin{array}{c}8.792 \\
(0.209)\end{array}$ & $\begin{array}{c}9.172 \\
(0.064)\end{array}$ \\
\hline Log value of dowry & $\begin{array}{c}9.371 \\
(0.032)\end{array}$ & $\begin{array}{c}9.939 \\
(0.163)\end{array}$ & $\begin{array}{c}9.791 \\
(0.117)\end{array}$ & $\begin{array}{c}9.803 \\
(0.176)\end{array}$ & $\begin{array}{c}9.27 \\
(0.034)\end{array}$ \\
\hline Education, bride & $\begin{array}{c}3.503 \\
(0.085)\end{array}$ & $\begin{array}{c}0.775 \\
(0.208)\end{array}$ & $\begin{array}{l}1.412 \\
(0.19)\end{array}$ & $\begin{array}{c}1.778 \\
(0.274)\end{array}$ & $\begin{array}{c}3.978 \\
(0.096)\end{array}$ \\
\hline Education, groom & $\begin{array}{l}3.653 \\
(0.09)\end{array}$ & $\begin{array}{c}1.625 \\
(0.336)\end{array}$ & $\begin{array}{c}2.181 \\
(0.268)\end{array}$ & $\begin{array}{c}2.404 \\
(0.371)\end{array}$ & $\begin{array}{c}3.994 \\
(0.1)\end{array}$ \\
\hline Age at marriage, bride & $\begin{array}{c}16.09 \\
(0.068)\end{array}$ & $\begin{array}{l}13.475 \\
(0.391)\end{array}$ & $\begin{array}{l}14.434 \\
(0.201)\end{array}$ & $\begin{array}{l}14.717 \\
(0.289)\end{array}$ & $\begin{array}{l}16.489 \\
(0.071)\end{array}$ \\
\hline Age at marriage, groom & $\begin{array}{l}23.996 \\
(0.108)\end{array}$ & $\begin{array}{l}23.887 \\
(0.616)\end{array}$ & $\begin{array}{l}24.335 \\
(0.413)\end{array}$ & $\begin{array}{l}23.707 \\
(0.513)\end{array}$ & $\begin{array}{l}23.981 \\
(0.116)\end{array}$ \\
\hline Bride's family richer & $\begin{array}{l}0.311 \\
(0.01)\end{array}$ & $\begin{array}{c}0.212 \\
(0.046)\end{array}$ & $\begin{array}{c}0.28 \\
(0.033)\end{array}$ & $\begin{array}{c}0.374 \\
(0.049)\end{array}$ & $\begin{array}{c}0.316 \\
(0.012)\end{array}$ \\
\hline Groom's family richer & $\begin{array}{l}0.234 \\
(0.01)\end{array}$ & $\begin{array}{c}0.313 \\
(0.052)\end{array}$ & $\begin{array}{c}0.231 \\
(0.031)\end{array}$ & $\begin{array}{c}0.172 \\
(0.038)\end{array}$ & $\begin{array}{c}0.235 \\
(0.011)\end{array}$ \\
\hline $\mathrm{N}$ (All female) & 1981 & 80 & 182 & 99 & 1620 \\
\hline
\end{tabular}

Figures in parentheses are standard errors. 
Table 2: Impact of exogenous shocks on the real values of mehr and dowry (PKSF 2010 data) base category: pre-GR (pre-1961)

\begin{tabular}{|c|c|c|c|c|}
\hline & $\begin{array}{c}\text { Log of Mehr } \\
\text { (1) }\end{array}$ & $\begin{array}{c}\text { Log of Dowry } \\
(2)\end{array}$ & $\begin{array}{c}\text { Log of Mehr } \\
(3)\end{array}$ & $\begin{array}{c}\text { Log of Dowry } \\
(4)\end{array}$ \\
\hline \multirow[t]{2}{*}{ GR (1961-1970) } & $0.672^{* *}$ & 0.13 & $0.589^{*}$ & 0.058 \\
\hline & $(1.987)$ & $(0.469)$ & $(1.783)$ & $(0.209)$ \\
\hline \multirow[t]{2}{*}{ IW-famine (1971-1974) } & 0.408 & 0.308 & 0.31 & 0.204 \\
\hline & $(0.867)$ & $(0.841)$ & $(0.674)$ & $(0.565)$ \\
\hline \multirow[t]{2}{*}{ Post-famine (post-1974) } & -0.491 & -0.3 & -0.46 & -0.339 \\
\hline & $(-0.848)$ & $(-0.720)$ & $(-0.819)$ & $(-0.825)$ \\
\hline Bride and groom's characteristics & No & No & Yes & Yes \\
\hline included? & & & & \\
\hline Number of observations & 1,981 & 1,981 & 1,981 & 1,981 \\
\hline R-squared & 0.182 & 0.212 & 0.214 & 0.255 \\
\hline \multirow[t]{2}{*}{ IW-famine relative to $\mathrm{GR}$} & -0.264 & 0.178 & -0.279 & 0.146 \\
\hline & $(-0.978)$ & $(0.809)$ & $(-1.044)$ & $(0.683)$ \\
\hline \multirow[t]{2}{*}{ Post-famine relative to GR } & $-1.163^{* * *}$ & $-0.431^{*}$ & $-1.049 * * *$ & $-0.397^{*}$ \\
\hline & $(-3.631)$ & $(-1.909)$ & $(-3.374)$ & $(-1.793)$ \\
\hline \multirow[t]{2}{*}{ Post-famine relative to IW-famine } & $-0.899 * * *$ & $-0.609 * * *$ & $-0.770 * * *$ & $-0.543^{* * *}$ \\
\hline & $(-3.336)$ & $(-3.123)$ & $(-2.905)$ & $(-2.862)$ \\
\hline \multicolumn{5}{|l|}{ p-value for $\chi^{2}$ test: } \\
\hline \multicolumn{5}{|l|}{ GR coefficient of mehr } \\
\hline$=\mathrm{GR}$ coefficient of dowry & & 0.2004 & & 0.2159 \\
\hline \multicolumn{5}{|l|}{ IW-famine coefficient of mehr } \\
\hline$=\mathrm{IW}$-famine coefficient of dowry & & 0.8496 & & 0.845 \\
\hline \multicolumn{5}{|l|}{ Post-famine coefficient of mehr } \\
\hline$=$ Post-famine coefficient of dwory & & 0.7956 & & 0.8723 \\
\hline
\end{tabular}
Robust t-statistics in parentheses; ${ }^{* *} p<0.01,{ }^{* *} p<0.05,{ }^{*} p<0.1$. 
Table 3: Impact of exogenous shocks on the real values of mehr and dowry (BRULS 2004 data) base category: pre-GR (pre-1961)

\begin{tabular}{|c|c|c|c|c|}
\hline & $\begin{array}{c}\text { Log of Mehr } \\
\text { (1) }\end{array}$ & $\begin{array}{l}\text { Log of Dowry } \\
(2)\end{array}$ & $\begin{array}{c}\text { Log of Mehr } \\
(3)\end{array}$ & $\begin{array}{c}\text { Log of Dowry } \\
(4)\end{array}$ \\
\hline GR (1961-1970) & $\begin{array}{c}1.54 \\
(1.257)\end{array}$ & $\begin{array}{c}1.076 \\
(0.883)\end{array}$ & $\begin{array}{c}1.245 \\
(0.981)\end{array}$ & $\begin{array}{c}0.491 \\
(0.406)\end{array}$ \\
\hline IW-famine (1971-1974) & $\begin{array}{c}1.625 \\
(1.228)\end{array}$ & $\begin{array}{c}1.042 \\
(0.797)\end{array}$ & $\begin{array}{c}1.212 \\
(0.895)\end{array}$ & $\begin{array}{l}0.361 \\
(0.28)\end{array}$ \\
\hline Post-famine (post-1974) & $\begin{array}{c}0.991 \\
(0.686)\end{array}$ & $\begin{array}{c}0.346 \\
(0.245)\end{array}$ & $\begin{array}{c}0.557 \\
(0.383)\end{array}$ & $\begin{array}{l}-0.344 \\
(-0.250)\end{array}$ \\
\hline $\begin{array}{l}\text { Bride and groom's characteristics } \\
\text { included? }\end{array}$ & No & No & Yes & Yes \\
\hline Observations & 1,367 & 1,367 & 1,364 & 1,364 \\
\hline R-squared & 0.136 & 0.11 & 0.205 & 0.244 \\
\hline IW-famine relative to GR & $\begin{array}{c}0.086 \\
(0.198)\end{array}$ & $\begin{array}{c}-0.034 \\
(-0.097)\end{array}$ & $\begin{array}{c}-0.034 \\
(-0.078)\end{array}$ & $\begin{array}{c}-0.13 \\
(-0.366)\end{array}$ \\
\hline Post-famine relative to GR & $\begin{array}{l}-0.549 \\
(-1.187)\end{array}$ & $\begin{array}{l}-0.730^{*} \\
(-1.864)\end{array}$ & $\begin{array}{l}-0.688 \\
(-1.523)\end{array}$ & $\begin{array}{l}-0.834^{* *} \\
(-2.218)\end{array}$ \\
\hline Post-famine relative to IW-famine & $\begin{array}{l}-0.634^{*} \\
(-1.806)\end{array}$ & $\begin{array}{l}-0.696^{* *} \\
(-2.441)\end{array}$ & $\begin{array}{l}-0.655^{*} \\
(-1.889)\end{array}$ & $\begin{array}{l}-0.704^{* *} \\
(-2.504)\end{array}$ \\
\hline $\begin{array}{l}\text { p-value for } \chi^{2} \text { test: } \\
\text { GR coefficient of mehr }\end{array}$ & & & & \\
\hline $\begin{array}{l}=\text { GR coefficient of dwory } \\
\text { IW-famine coefficient of mehr }\end{array}$ & & 0.661 & & 0.502 \\
\hline$=\mathrm{IW}$-famine coefficient of dwory & & 0.609 & & 0.48 \\
\hline $\begin{array}{l}\text { Post-famine coefficient of mehr } \\
=\text { Post-famine coefficient of dwory }\end{array}$ & & 0.602 & & 0.485 \\
\hline
\end{tabular}

Robust t-statistics in parentheses; ${ }^{* * *} p<0.01,{ }^{* *} p<0.05,{ }^{*} p<0.1$. All regressions control for dummies for relationship with the household head, dummies for regions, and a constant. 
Table 4: Impact of exogenous shocks on the real values of mehr and dowry (PKSF + BRULS data) base category: pre-GR (pre-1961)

\begin{tabular}{|c|c|c|c|c|}
\hline & $\begin{array}{l}\text { Log of Mehr } \\
\text { (1) }\end{array}$ & $\begin{array}{l}\text { Log of Dowry } \\
(2)\end{array}$ & $\begin{array}{c}\text { Log of Mehr } \\
(3)\end{array}$ & $\begin{array}{c}\text { Log of Dowry } \\
\text { (4) }\end{array}$ \\
\hline GR (1961-1970) & $\begin{array}{c}1.036^{* * *} \\
(3.244)\end{array}$ & $\begin{array}{c}0.255 \\
(0.913)\end{array}$ & $\begin{array}{c}0.877^{* * *} \\
(2.823)\end{array}$ & $\begin{array}{c}0.112 \\
(0.418)\end{array}$ \\
\hline IW-famine (1971-1974) & $\begin{array}{c}0.946^{* *} \\
(2.24)\end{array}$ & $\begin{array}{l}0.353 \\
(1.01)\end{array}$ & $\begin{array}{l}0.766^{*} \\
(1.871)\end{array}$ & $\begin{array}{c}0.179 \\
(0.533)\end{array}$ \\
\hline Post-famine (post-1974) & $\begin{array}{c}0.235 \\
(0.465)\end{array}$ & $\begin{array}{l}-0.369 \\
(-0.938)\end{array}$ & $\begin{array}{c}0.12 \\
(0.246)\end{array}$ & $\begin{array}{c}-0.481 \\
(-1.280)\end{array}$ \\
\hline $\begin{array}{l}\text { Bride and groom's characteristics } \\
\text { included? }\end{array}$ & No & No & Yes & Yes \\
\hline Observations & 3,348 & 3,348 & 3,345 & 3,345 \\
\hline R-squared & 0.209 & 0.158 & 0.253 & 0.233 \\
\hline IW-famine relative to GR & $\begin{array}{l}-0.089 \\
(-0.383)\end{array}$ & $\begin{array}{c}0.097 \\
(0.509)\end{array}$ & $\begin{array}{c}-0.112 \\
(-0.492)\end{array}$ & $\begin{array}{c}0.066 \\
(0.359)\end{array}$ \\
\hline Post-famine relative to GR & $\begin{array}{c}-0.800 * * * \\
(-2.992)\end{array}$ & $\begin{array}{c}-0.624^{* * *} \\
(-3.207)\end{array}$ & $\begin{array}{c}-0.757^{* * *} \\
(-2.973)\end{array}$ & $\begin{array}{c}-0.593^{* * *} \\
(-3.177)\end{array}$ \\
\hline Post-famine relative to IW-famine & $\begin{array}{c}-0.711^{* * *} \\
(-3.236) \\
\end{array}$ & $\begin{array}{c}-0.721^{* * *} \\
(-4.367) \\
\end{array}$ & $\begin{array}{c}-0.646^{* * *} \\
(-3.021) \\
\end{array}$ & $\begin{array}{c}-0.660 * * * \\
(-4.147) \\
\end{array}$ \\
\hline $\begin{array}{l}\text { p-value for } \chi^{2} \text { test: } \\
\text { GR coefficient of mehr }\end{array}$ & & & & \\
\hline $\begin{array}{l}=\mathrm{GR} \text { coefficient of dwory } \\
\text { IW-famine coefficient of mehr }\end{array}$ & & 0.039 & & 0.045 \\
\hline $\begin{array}{l}=\text { IW-famine coefficient of dwory } \\
\text { Post-famine coefficient of mehr }\end{array}$ & & 0.228 & & 0.236 \\
\hline$=$ Post-famine coefficient of dwory & & 0.292 & & 0.296 \\
\hline
\end{tabular}

Robust t-statistics are in parentheses; ${ }^{* * *} p<0.01,{ }^{* *} p<0.05,{ }^{*} p<0.1$. All regressions control for the dummies for relationship with the household head, dummies for the regions, and a constant. 
Table 5: Impact of exogenous shocks on the real values of mehr and dowry in West Bengal (pre-GR is the base category)

\begin{tabular}{|c|c|c|c|c|}
\hline & $\begin{array}{c}\text { Log of Mehr } \\
\text { (1) }\end{array}$ & $\begin{array}{c}\text { Log of Dowry } \\
(2) \\
\end{array}$ & $\begin{array}{c}\text { Log of Mehr } \\
(3)\end{array}$ & $\begin{array}{c}\text { Log of Dowry } \\
(4) \\
\end{array}$ \\
\hline GR (1961-1974) & $\begin{array}{l}1.608^{* *} \\
(2.141)\end{array}$ & $\begin{array}{c}0.228 \\
(0.109)\end{array}$ & $\begin{array}{l}1.308^{*} \\
(1.709)\end{array}$ & $\begin{array}{l}-0.361 \\
(-0.176)\end{array}$ \\
\hline Post-1974 & $\begin{array}{l}1.757^{* *} \\
(2.022)\end{array}$ & $\begin{array}{l}-0.812 \\
(-0.345)\end{array}$ & $\begin{array}{c}1.342 \\
(1.532)\end{array}$ & $\begin{array}{c}-1.347 \\
(-0.586)\end{array}$ \\
\hline $\begin{array}{l}\text { Bride and groom's characteristics } \\
\text { included? }\end{array}$ & No & No & Yes & Yes \\
\hline Number of observations & 1,158 & 1,186 & 1,158 & 1,186 \\
\hline R-squared & 0.202 & 0.131 & 0.235 & 0.214 \\
\hline Post-1974 relative to GR & $\begin{array}{c}0.149 \\
(0.455)\end{array}$ & $\begin{array}{c}-1.039 \\
(-1.268)\end{array}$ & $\begin{array}{c}0.033 \\
(0.105)\end{array}$ & $\begin{array}{c}-0.986 \\
(-1.237)\end{array}$ \\
\hline $\begin{array}{l}\text { p-value for } \chi^{2} \text { test: } \\
\text { GR coefficient of mehr } \\
=\text { GR coefficient of dwory }\end{array}$ & & 0.504 & & 0.409 \\
\hline $\begin{array}{l}\text { Post- } 1974 \text { coefficient of mehr } \\
=\text { Post-1974 coefficient of dwory }\end{array}$ & & 0.27 & & 0.238 \\
\hline
\end{tabular}




\section{Appendix 1: Dowry determined through Nash Bargaining}

So far dowry has been interpreted as a groom price that clears the marriage market. We now examine a related framework where dowry is instead determined through Nash bargaining. Such a framework may not be too far fetched, given that marriages in these societies often involve negotiations between two families. However, as in the baseline framework, mehr is taken to be a conditional payment that serves to prevent inefficient divorce. The framework is the same as before, except that we assume that the economy consists of exactly one man, and one woman, so as to abstract from issues related to matching. Doing so also abstracts from any competitive forces operating here.

Further, for ease of exposition, we assume that there are two kinds of marriages, successful and average, with the marriage being successful with probability $\gamma_{s}$ and average with probability $1-\gamma_{s}$. The marriage parameter is $S$ in case of a successful marriage, and $t$ in case it is a failure. We assume that in case the marriage is average, then it is efficient that divorce does not happen, but, in the absence of mehr, men have an incentive to get divorced, i.e.

$$
m \mu_{m}+w \mu_{w}<t(m+w), \quad \mu_{m}>t .
$$

We shall argue that there is a close and intuitive connection between the dowry in this case with that in the baseline framework. For ease of exposition we also assume that men do not have any property rights over their wife's income.

The timeline is as follows:

- Stage 1: The man and the woman bargain over the surplus. If they reach an agreement then marriage takes place and the agreement is codified in a contract $(D, M)$, with the amount $D$ being paid upfront.

- Stage 2: Following a marriage, the man and the woman realize if the marriage is a success or a failure, and the man decides whether to get divorced or not. In case of divorce, man pays the woman the agreed upon mehr $M$.

In this framework an equilibrium is a vector $\left(D^{*}, M^{*}\right)$ and a divorce rule such that:

1. The man takes the divorce decision in his own interest, given the contract $\left(D^{*}, M^{*}\right)$ and the state of the marriage.

2. $M^{*}$ is the minimum level of mehr such that inefficient divorce is prevented.

3. The dowry $D^{*}$ is set through Nash bargaining between the man and the woman.

We next turn to solving for the equilibrium mehr and dowry. It is clear that one can mimic the argument in the main text to argue that Proposition 1 holds in this case as well. Further, given $\mu_{m}>t$, mehr is positive. 
Turning to dowry, we then solve for the Nash bargaining game between the man and the woman, where the bargaining power of the man is $\beta$, and that of the woman is $1-\beta, 0<\beta<1$. Letting $H$ (respectively $W$ ) denote the utility of the man (respectively the woman) in this bargaining game, one can define the set of feasible outcomes

$\mathcal{F}=\left\{(H, W) \mid H+W \leq \gamma_{s} S(m+w)+\left(1-\gamma_{s}\right) \max \left\{t(m+w), \mu_{m} m+\mu_{w} w\right\}, H \geq \mu_{m} m, W \geq \mu_{w} w\right\}$.

Observe that the frontier of the feasible set is derived using the fact that efficiency entails the marriage taking place, as well as divorce, if any, being efficiency enhancing. Given that $m \mu_{m}+w \mu_{w}<t(m+w)$, we have that

$$
\mathcal{F}=\left\{(H, W) \mid H+W \leq \gamma_{s} S(m+w)+\left(1-\gamma_{s}\right) t(m+w), H \geq \mu_{m} m, W \geq \mu_{w} w\right\} .
$$

The Nash bargaining program, call it $\left(H^{*}, W^{*}\right)$, solves

$$
\begin{array}{cl}
\max _{H, W} & \left(H-m \mu_{m}\right)^{\beta}\left(W-w \mu_{w}\right)^{(1-\beta)} \\
\text { s.t. } & (H, W) \in \mathcal{F} .
\end{array}
$$

Implementing this $\left(H^{*}, W^{*}\right)$ will require transfers among agents, which is the role played by dowry in this framework. Let the corresponding dowry be denoted $D^{*}$.

We then solve for the equilibrium level of dowry $D^{*}$. The man's expected payoff following Nash bargaining is given by

$$
m \mu_{m}+\beta\left[\left(\gamma_{s} S+\left(1-\gamma_{s}\right) t\right)(m+w)-m \mu_{m}-w \mu_{w}\right] .
$$

Equating this with $\gamma_{s} S m+\left(1-\gamma_{s}\right) t m+D^{*}$, we find that the dowry

$$
D^{*}=m\left(\mu_{m}-\gamma_{s} S-\left(1-\gamma_{s}\right) t\right]+\beta\left[\left(\gamma_{s} S+\left(1-\gamma_{s}\right) t\right)(m+w)-m \mu_{m}-w \mu_{w}\right],
$$

where recall that $m\left[\mu_{m}-\gamma_{s} S-\left(1-\gamma_{s}\right) t\right]$ equals the dowry in our baseline framework whenever $t=t_{a}$ and $\gamma_{f}=0$. Thus we get back the competitive dowry in the limit as the bargaining power of groom families vanish, i.e. $\beta$ goes to zero.

All the comparative statics results go through as long as $\beta$ is not too large. Whether $\beta$ is large or small is of course an empirical question, and depends on multiple factors. While, on the one hand, the fact that the societal norms are biased in favour of men suggest that $\beta$ will not be too small; on the other hand, the competitive forces arising from the fact that men are more numerous vis-á-vis women suggest that $\beta$ cannot be too large ${ }^{46}$ A more realistic model would possibly have elements of both marriage market competition, as well as inter-family bargaining. That must await future work though.

\footnotetext{
${ }^{46}$ Suppose $\beta=\frac{1}{2}$ and an income shock causes identical proportionate changes in the income of men and women. Then $d M^{*}-d D^{*}=\frac{1}{2}\left[\mu_{m}+\mu_{w}-2 t\right] \frac{d w}{w}$. Thus an income shock causes a greater change in mehr whenever $\mu_{m}+\mu_{w}-2 t>0$.
} 


\section{Appendix 2: Figures and Tables}

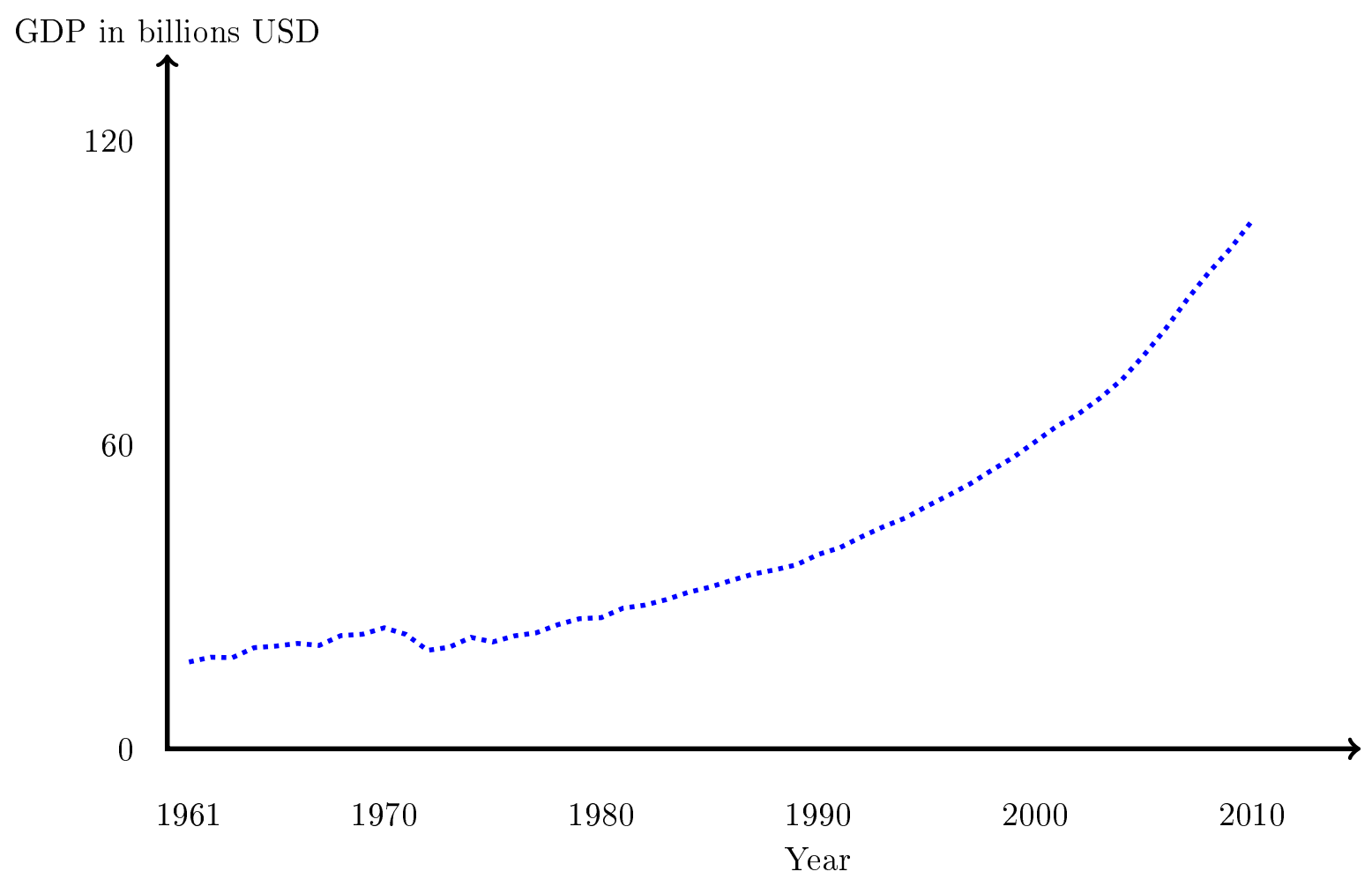

Figure-A1a: GDP of Bangladesh in costant USD, 1961-2010, Data Source: WDI 


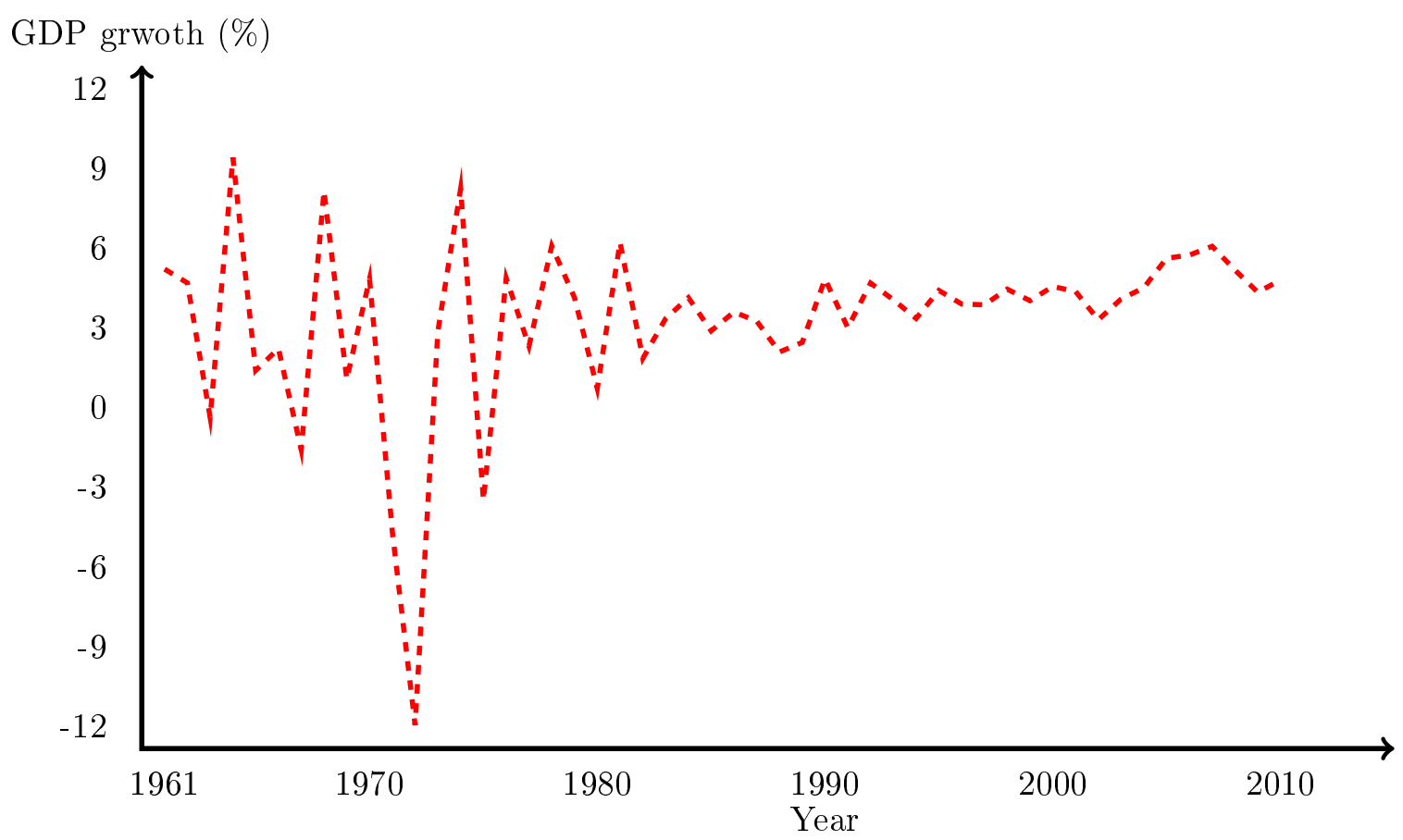

Figure-A1b: GDP Growth, 1961-2010, Data Source: World Development Indicators 


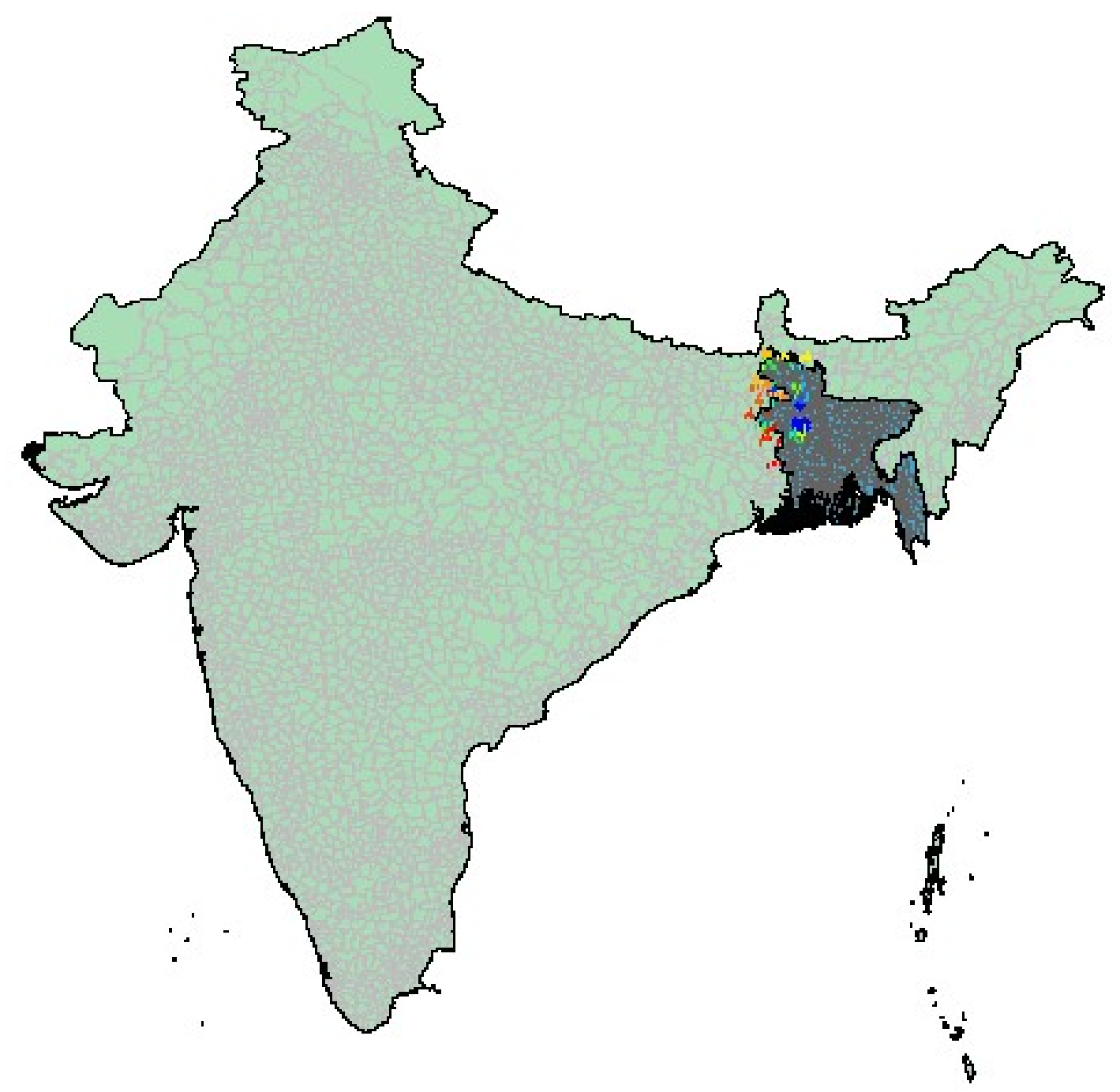

Figure A2: Data Collection Regions in Bangladesh and India 


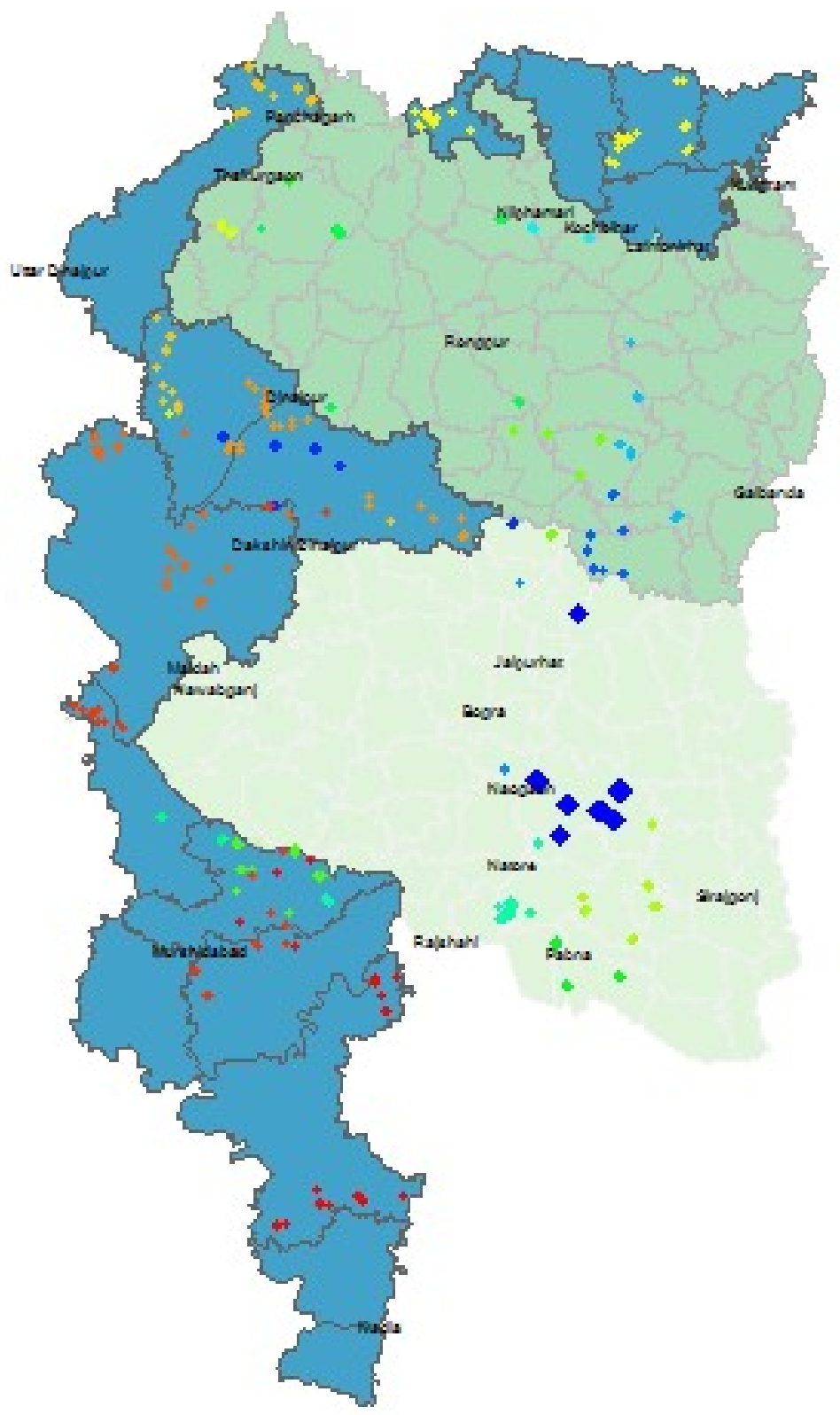

Figure A3: Location of Study Villages in Bangladesh (BRULS data) and West Bengal 


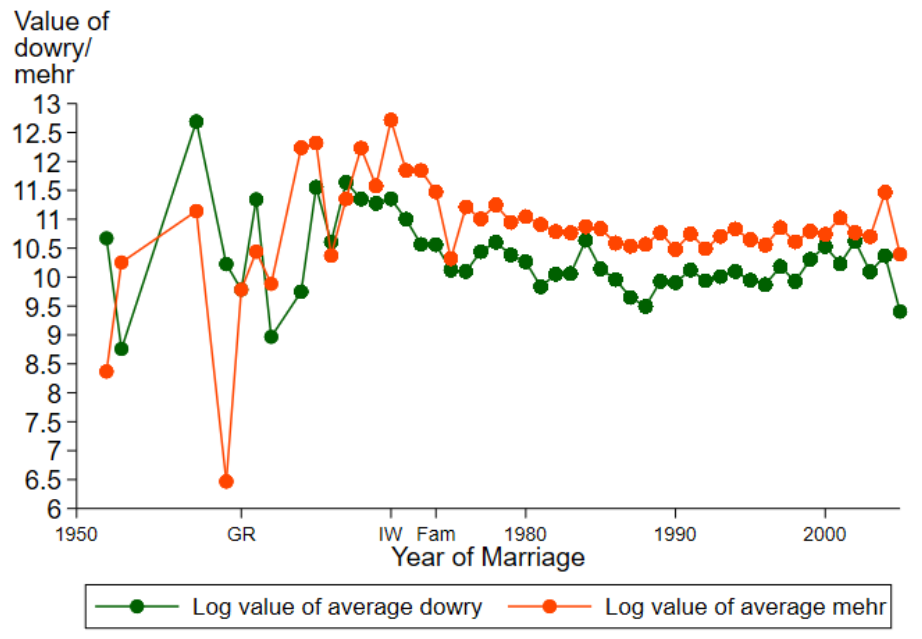

Figure A4: Mean Real Value of Mehr and Dowry by Year of Marriage BRULS (2004) data

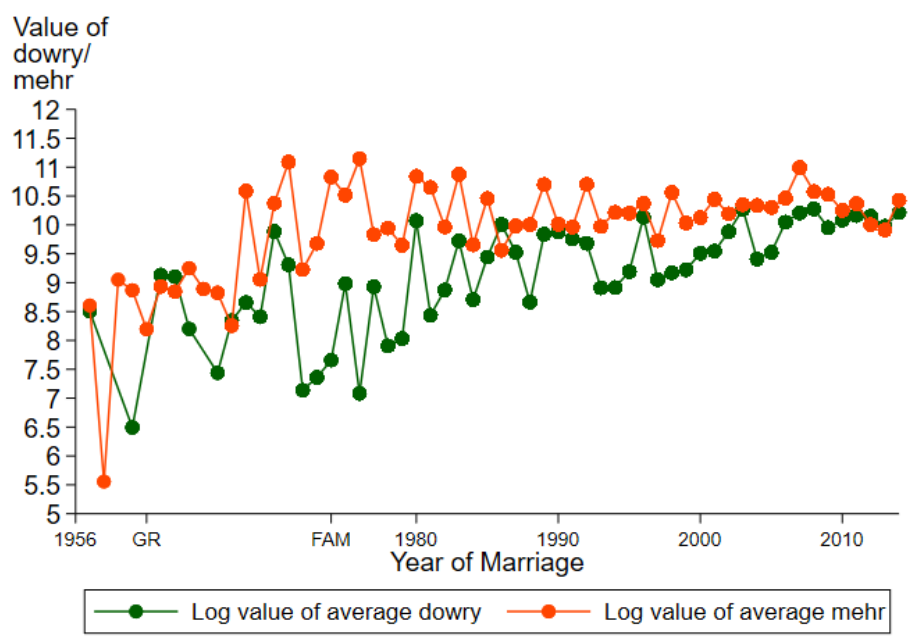

Figure A5: Mean Real Value of Mehr and Dowry by Year of Marriage West Bengal data 
Table A1: Summary Statistics - BRULS (2004-05) data

\begin{tabular}{lccccc}
\hline \hline & All & Regime I & Regime II & Regime III & Regime IV \\
& Marriages & Marriages & Marriages & Marriages & Marriages \\
& over & $($ before & $(1961-$ & $(1971-$ & $(1975-$ \\
& the period & $1961)$ & $1970)$ & $1974)$ & $2004)$ \\
& $(1)$ & $(2)$ & $(3)$ & $(4)$ & $(5)$ \\
\hline Log value of mehr & 10.317 & 9.615 & 10.825 & 10.883 & 10.288 \\
Log value of dowry & $(0.034)$ & $(0.999)$ & $(0.295)$ & $(0.313)$ & $(0.033)$ \\
& 9.674 & 10.659 & 10.746 & 10.445 & 9.608 \\
Education, bride & $(0.03)$ & $(1.086)$ & $(0.235)$ & $(0.231)$ & $(0.029)$ \\
& 3.113 & 1.125 & 1.289 & 1.694 & 3.23 \\
Education, groom & $(0.102)$ & $(0.743)$ & $(0.389)$ & $(0.521)$ & $(0.106)$ \\
Age at marriage, bride & 3.754 & 3.429 & 2.733 & 2.889 & 3.817 \\
& $(0.107)$ & $(1.478)$ & $(0.522)$ & $(0.65)$ & $(0.111)$ \\
Age at marriage, groom & 15.739 & 12.375 & 13.822 & 14.528 & 15.862 \\
Bride's family richer & $(0.075)$ & $(1.117)$ & $(0.364)$ & $(0.45)$ & $(0.076)$ \\
& 22.636 & 21.75 & 22.622 & 22.306 & 22.652 \\
Groom's family richer & $(0.108)$ & $(0.861)$ & $(0.564)$ & $(0.701)$ & $(0.112)$ \\
& 0.345 & 0.5 & 0.356 & 0.222 & 0.347 \\
N (All female) & $(0.013)$ & $(0.189)$ & $(0.072)$ & $(0.07)$ & $(0.013)$ \\
& 0.296 & 0.5 & 0.356 & 0.333 & 0.292 \\
& $(0.012)$ & $(0.189)$ & $(0.072)$ & $(0.08)$ & $(0.013)$ \\
& 1367 & 8 & 45 & 36 & 1278 \\
\hline
\end{tabular}

Figures in parentheses are standard errors. 
Table A2: Summary Statistics - West Bengal (2014-15) data

\begin{tabular}{lcccc}
\hline \hline & All & Regime I & Regime II & Regime III \\
& Marriages & Marriages & Marriages & Marriages \\
& over & (before & $(1961-$ & $(1974-$ \\
& the period & $1961)$ & $1974)$ & $2014)$ \\
& $(1)$ & $(2)$ & $(3)$ & $(4)$ \\
\hline Log value of mehr & 9.101 & 7.52 & 8.904 & 9.121 \\
Log value of dowry & $(0.052$ & $(0.806)$ & $(0.154)$ & $(0.054)$ \\
Education, bride (in years of schooling) & 7.499 & 3.377 & 5.072 & 7.701 \\
Education, groom (in years of schooling) & $(0.106$ & $(2.071)$ & $(0.46)$ & $(0.107)$ \\
Age at marriage, bride (in years) & 3.64 & 0.16 & 0.89 & 3.9 \\
Age at marriage, groom (in years) & $(0.12)$ & $(0.16)$ & $(0.23)$ & $(0.12)$ \\
Bride's family richer (yes=1, 0 otherwise) & 3.68 & 0.32 & 2.11 & 3.85 \\
Groom's family richer (yes =1, 0 otherwise) & $0.12)$ & $(0.23)$ & $(0.35)$ & $(0.13)$ \\
& 16.5 & 12.74 & 14.14 & 16.74 \\
N (All female) & $(0.1)$ & $(0.7)$ & $(0.3)$ & $(0.1)$ \\
\hline
\end{tabular}

Numbers in parentheses are standard errors. 
Table A3: Impact of exogenous shocks - PKSF 2010 data restricted to 1989 (base category: pre-GR (pre-1961))

\begin{tabular}{lcccc}
\hline \hline & \multicolumn{2}{c}{ Log of Mehr } & \multicolumn{2}{c}{ Log of Dowry } \\
& $(1)$ & $(2)$ & $(3)$ & $(4)$ \\
\hline GR (1961-1970) & $1.025^{* * *}$ & $0.940^{* *}$ & 0.126 & 0.162 \\
& $(2.810)$ & $(2.560)$ & $(0.337)$ & $(0.442)$ \\
IW-famine (1971-1974) & $0.854^{*}$ & 0.719 & 0.332 & 0.357 \\
& $(1.742)$ & $(1.439)$ & $(0.680)$ & $(0.746)$ \\
Post-famine (post-1974) & -0.014 & -0.089 & -0.145 & -0.110 \\
& $(-0.026)$ & $(-0.159)$ & $(-0.272)$ & $(-0.210)$
\end{tabular}

$\begin{array}{lllll}\text { Bride and groom's characteristics } & \text { No } & \text { Yes } & \text { No } & \text { Yes }\end{array}$ included?

\begin{tabular}{lcccc} 
Number of observations & 1,023 & 1,023 & 1,023 & 1,023 \\
R-squared & 0.093 & 0.143 & 0.208 & 0.251 \\
\hline IW-famine relative to GR & -0.171 & -0.221 & 0.206 & 0.195 \\
& $(-0.642)$ & $(-0.815)$ & $(0.889)$ & $(0.861)$ \\
Post-famine relative to GR & $-1.040^{* * *}$ & $-1.029^{* * *}$ & -0.271 & -0.272 \\
& $(-3.151)$ & $(-3.190)$ & $(-1.095)$ & $(-1.109)$ \\
Post-famine relative to IW-famine & $-0.869^{* * *}$ & $-0.808^{* * *}$ & $-0.476^{* *}$ & $-0.466^{* *}$ \\
& $(-3.013)$ & $(-2.853)$ & $(-2.345)$ & $(-2.369)$ \\
\hline
\end{tabular}

Figures in parentheses are robust t-values clustered at the household level. ${ }^{* * *} p<0.01,{ }^{* *}$ $p<0.05,{ }^{*} p<0.1$. 
Table A4: West Bengal data - GR is restricted to 1970 (pre-GR is the base category)

\begin{tabular}{lcccc}
\hline \hline & \multicolumn{2}{c}{ Log of Mehr } & \multicolumn{2}{c}{ Log of Dowry } \\
& $(1)$ & $(2)$ & $(3)$ & $(4)$ \\
\hline GR (1961-1970) & $1.560^{* *}$ & $1.294^{*}$ & 0.510 & -0.121 \\
& $(2.099)$ & $(1.709)$ & $(0.246)$ & $(-0.059)$ \\
Post-1970 & $1.669^{*}$ & 1.249 & -0.928 & -1.735 \\
& $(1.957)$ & $(1.451)$ & $(-0.409)$ & $(-0.780)$
\end{tabular}

$\begin{array}{lllll}\text { Bride and groom's characteristics } & \text { No } & \text { Yes } & \text { No } & \text { Yes }\end{array}$ included?

Number of observations $\quad 1,158 \quad 1,158 \quad 1,186 \quad 1,186$

\begin{tabular}{lcccc} 
R-squared & 0.202 & 0.235 & 0.133 & 0.216 \\
\hline Post-1970 relative to GR & 0.109 & -0.046 & $-1.438^{*}$ & $-1.614^{*}$
\end{tabular}

$\begin{array}{llll}(0.323) & (-0.137) \quad(-1.664) \quad(-1.899)\end{array}$

Figures in parentheses are robust t-values clustered at the household level. ${ }^{* * *} p<0.01,{ }^{* *}$ $p<0.05,{ }^{*} p<0.1$.

Table A5: Gender Ratio (male divided by female) by Age Group, 1951-2011

\begin{tabular}{lcccccc}
\hline \hline Age Group & 1951 & 1961 & 1974 & 1981 & 1991 & 2011 \\
\hline $0-4$ & 0.990 & 0.978 & 0.993 & 1.014 & 1.029 & 1.029 \\
$5-9$ & 1.038 & 1.045 & 1.012 & 1.030 & 1.070 & 1.053 \\
$10-14$ & 1.263 & 1.281 & 1.189 & 1.148 & 1.145 & 1.073 \\
$15-24$ & 0.973 & 0.943 & 1.059 & 0.976 & 0.947 & 0.981 \\
$25-34$ & 1.060 & 1.043 & 0.969 & 1.015 & 0.975 & 0.892 \\
$35-44$ & 1.207 & 1.188 & 1.148 & 1.110 & 1.178 & 1.016 \\
$45-59$ & 1.306 & 1.263 & 1.238 & 1.209 & 1.160 & 1.145 \\
$60+$ & 1.227 & 1.229 & 1.299 & 1.277 & 1.200 & 1.135 \\
\hline
\end{tabular}




\section{Appendix 3: Replication of Ambrus et al. (2010) using the BRULS data}

In the following, we discuss Ambrus et al. (2010) who also analyze a framework with deferred mehr, attributing the changes in dowry and mehr to the legal shocks discussed in Section 2.2. We first compare our theoretical framework with theirs, before turning to some important differences in estimations and results.

Apart from the difference in focus, the theoretical framework developed in the present paper also generates results that are different from those in Ambrus et al. (2010). For one, our analysis suggests that the legal shock in the 1960s, i.e. the MFLO, would cause a decline in mehr and dowry, rather than an increase as in Ambrus et al. (2010). As far as the effect of the MMDA is concerned, the theoretical predictions in the two papers do coincide, in that both suggest that mehr and dowry would be adversely affected, at least in the short run. Additionally, in our framework an income shock will have a smaller effect on dowry relative to that on mehr, while in Ambrus et al. (2015) dowry and mehr co-move. In fact, this result goes through even if we extend the framework to one where mehr payments are made in equilibrium, creating a link between mehr and dowry. These differences can be traced to the fact that in our framework dowry is not a price paid for mehr. We focus on efficient equilibria where mehr ensures that inefficient divorces do not take place, while dowry essentially serves to clear the marriage market. Further, unlike Ambrus et al. (2010), we do not assume that mehr is non-negative, this is something that emerges naturally in our framework. Ambrus et al. (2010) provides an institutional justification for this assumption, pointing out that negative mehr is forbidden in the Qur'an, so that religious courts do not enforce contracts with negative mehr. This justification is valid for the present framework as well.

Before replicating the estimation by Ambrus et al. (2010), it is imperative to note that these authors used the BRULS dataset but employed a different and extensive cleaning procedure to construct their working data. This involves changing the values of dowry and mehr recorded in the survey; their cleaning code in STATA has become available to us through the Quarterly Journal of Economics (QJE). We also received an acknowledgment from these authors through the QJE that a small perturbation in the cleaning procedure leads to changes their main results. They only mentioned in the paper how their working sample is selected from the households included in the survey (in Section IV.A in their paper), but not their data cleaning procedure. Our (BRULS) data construction and working sample selection, discussed in Section 5, do not involve any such cleaning as imputation of missing values or changing the recorded values.

Ambrus et al. (2010) estimated the same equations as 30 and 31 with the exceptions that the values of dowry and mehr were not expressed in logarithm and the attributes of the brides and grooms were excluded. Their identifying assumption is that the legal changes in 1961 and 1974 did not coincide with any other changes that may have influenced dowry and mehr. 
More importantly, they divided the entire period into seven equal (eight year) sub-periods, and included these sub-period dummies as additional controls in their regressions. We show below that their results crucially depend on inclusion of these ad hoc dummies. As stated in their paper, these dummies were included to account for non-linearity in the trends of dowry and mehr. However, the movements in the values of dowry and mehr displayed in Figure 2 do not suggest cyclical patterns repeating every eight years as in the business-cycle literature. Moreover, the pattern of business-cycle fluctuations of GDP in Bangladesh (Appendix 3, Figures A1a-A1b) is different from that in developed countries, especially that in the USA (see Baxter and King (1999) for the patterns of business-cycle in the USA), so inclusion of these dummies cannot also be justified on the ground of controlling for fluctuations in aggregate economic activity in Bangladesh. These dummies rather confound the interpretation of dummies of legal changes. The coefficients of these sub-period dummies provide estimates of the average value of dowry or mehr in each sub-period relative to the base category. Similarly, the dummies for the legal changes also provide estimates of the average value of dowry or mehr in the respective periods (relative to the base category). Given that these two sets of dummies substantially overlap with one another, it is not clear what the dummies for legal changes capture.

We first replicate the Ambrus et al. (2010) benchmark results (Ambrus et al. (2010) Table II, p.1384) using their cleaned data (http://sites.duke.edu/ericafield/data/ (accessed March 19, 2014)). Despite minor differences in magnitudes, we can replicate their benchmark results in Table A6 (columns 1 and 2). The two legal changes, the MFLO and the MMDA, are represented by post-1963 and post-1974, respectively. Post-1990 and post-1998 represent two other legal changes. As found in Ambrus et al. (2010), the first two legal changes had statistically significant impact on both mehr and dowry. 


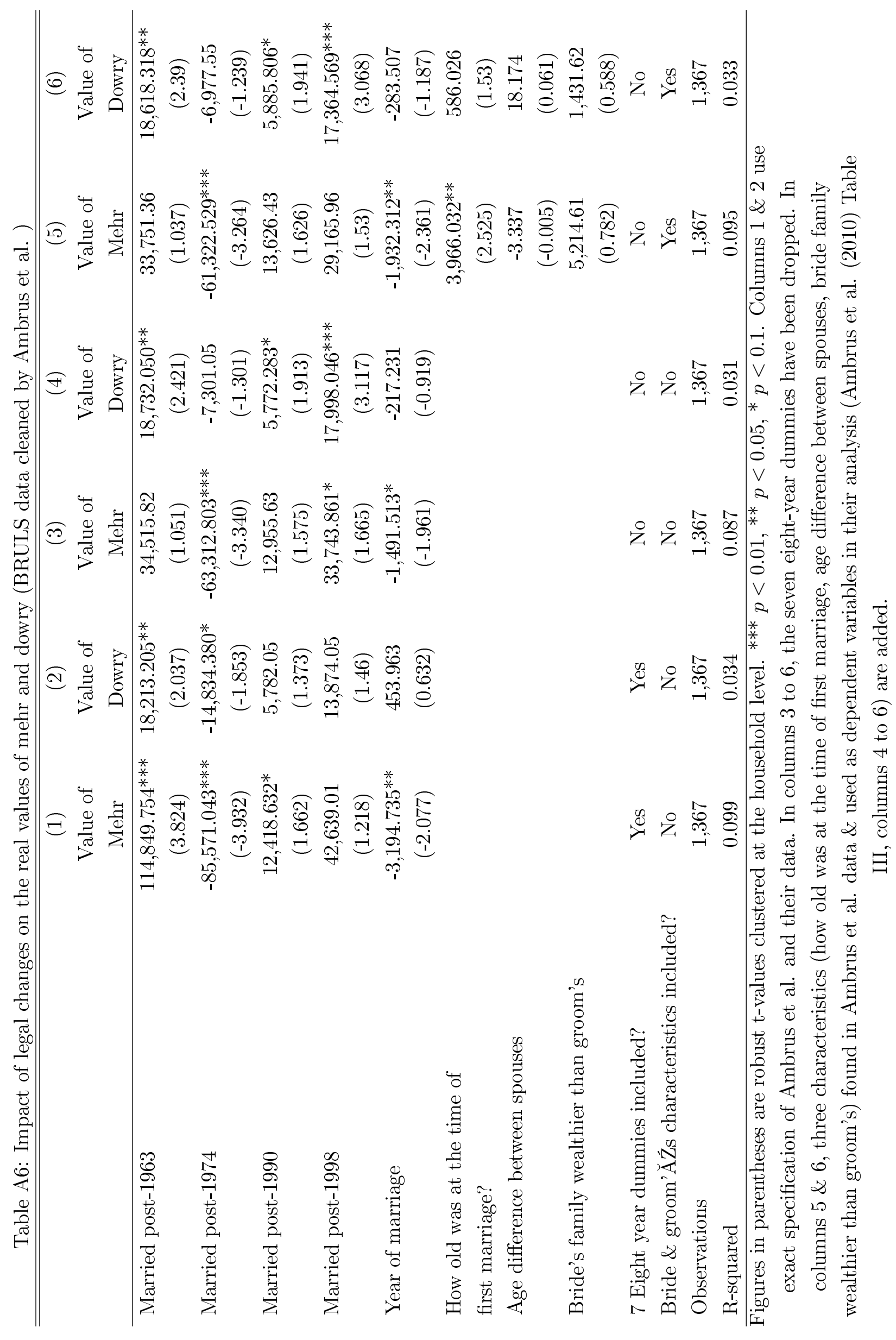


We now verify whether the above results are due to the inclusion of the ad hoc eight-year sub-period dummies. The results for mehr and dowry excluding these dummies are presented in columns (3) and (4), respectively. In the case of the value of mehr, the magnitude of the coefficient of the MFLO (the first legal change), is not statistically significant and much smaller. Similarly in the case of the value of dowry, the magnitude of the coefficient of the MMDA (the second legal change) is also not statistically significant and again much smaller. Thus, their main results do not hold. The results after controlling for the bride and groom characteristics, reported in columns 5 and 6 , are very similar to those in columns 3 and 4 .

We now estimate the benchmark specification of Ambrus et al. (2010) using our data, and we use the merged (BRULS and PKSF) datasets to take advantage of a larger and more representative sample. To be consistent with Ambrus et al. (2010), we retain marriages from the PKSF dataset only through 2004. The results are presented in Table A7. Columns 1 and 2 exactly replicate the specification in Table II in Ambrus et al. (2010) including the sub-period dummies. Columns 3 and 4 exclude the sub-period dummies, for reasons discussed earlier. In both cases, we find no impact of any legal changes on the values of mehr or dowry. To summarize, we find that the results in Ambrus et al. (2010) are not robust to alternative data cleaning procedure, modest changes in specification, or using alternative data.

Difference in the data cleaning procedure is a non-trivial issue and requires further attention. We therefore investigate whether our explanation of the role of natural shocks holds in the BRULS data cleaned by Ambrus et al. (2010). The results are presented in Table A8. It is important to reiterate that Ambrus et al. (2010) replaced many recorded (and missing) values by 0s in the cleaning procedure; therefore, logarithmic transformation reduces the effective sample size by about $30 \%$ in the dowry equation, which is a non-trivial change in the data. Nonetheless, the results show that they are qualitatively very similar to the results reported in Tables 2-4. Although the value of mehr in the GR period relative to the pre-GR period is now negative, it remains statistically insignificant as in Table 3 based on the BRULS data following our own cleaning procedure. 
Table A7: Impact of legal changes on the real values of mehr and dowry (PKSF + BRULS data) alternative specification)

\begin{tabular}{lcccc}
\hline \hline & $\begin{array}{c}\text { Value of } \\
\text { Mehr }\end{array}$ & $\begin{array}{c}\text { Value of } \\
\text { Dowry }\end{array}$ & $\begin{array}{c}\text { Value of } \\
\text { Mehr }\end{array}$ & $\begin{array}{c}\text { Value of } \\
\text { Dowry } \\
\end{array}$ \\
& $(1)$ & $(2)$ & $(3)$ & $(4)$ \\
\hline Post-1963 & $-11,834.07$ & $-18,108.57$ & $48,888.49$ & $14,882.17$ \\
& $(-0.251)$ & $(-0.878)$ & $(1.598)$ & $(0.747)$ \\
Post-1974 & $-58,680.68$ & $-30,113.34$ & $8,404.67$ & $-27,002.88)$ \\
& $(-1.024)$ & $(-1.310)$ & $(0.253)$ & $(-1.519)$ \\
Post-1990 & $-47,682.42$ & $-25,948.56$ & $9,473.20$ & $-20,175.85$ \\
& $(-0.835)$ & $(-1.065)$ & $(0.262)$ & $(-1.081)$ \\
Post-1998 & $-29,380.52$ & $-12,113.44$ & $33,173.32$ & $-1,931.23$ \\
& $(-0.506)$ & $(-0.479)$ & $(0.837)$ & $(-0.097)$ \\
7 Eight year dummies included? & Yes & Yes & No & No \\
Observations & 2,996 & 2,996 & 2,996 & 2,996 \\
R-squared & 0.077 & 0.069 & 0.064 & 0.058 \\
\hline
\end{tabular}

Robust t-statistics are in parentheses; ${ }^{* *} p<0.01,{ }^{* *} p<0.05,{ }^{*} p<0.1$. All regressions control for dummies for relationship with household head, marriage year, dummies for regions, seven 8-year period dummies, and a constant. Columns (3) and (4) do not include seven 8-year period dummies. 
Table A8: Impact of exogenous shocks on the real values of mehr and dowry (BRULS data cleaned by Ambrus et al. (2010) ) base category: pre-GR (pre-1961)

\begin{tabular}{lcc}
\hline \hline & $\begin{array}{c}\text { Log of } \\
\text { Mehr }\end{array}$ & $\begin{array}{c}\text { Log of } \\
\text { Dowry }\end{array}$ \\
& $(1)$ & $(2)$ \\
\hline GR (1961-1970) & -0.024 & -0.038 \\
& $(-0.064)$ & $(-0.066)$ \\
IW-famine (1971-1974) & -0.026 & -0.719 \\
& $(-0.063)$ & $(-1.217)$ \\
Post-famine (post-1974) & -0.6 & $-1.925^{* * *}$ \\
Observations & $(-1.543)$ & $(-3.326)$ \\
R-squared & 1,367 & 915 \\
\hline IW-famine relative to GR & 0.097 & 0.091 \\
\hline & -0.002 & $-0.681^{* *}$ \\
Post-famine relative to GR & $-0.009)$ & $(-2.340)$ \\
Post-famine relative to IW-famine & $-0.576^{* * *}$ & $-1.887^{* * *}$ \\
& $(-2.760)$ & $(-7.427)$ \\
& $(-2.393)$ & $-1.206^{* * *}$ \\
\end{tabular}

Figures in parentheses are robust t-values clustered at the household level. ${ }^{* * *} p<0.01,{ }^{* *}$

$$
p<0.05, * p<0.1 \text {. }
$$

